\title{
SAKRY I SUKCESJA ŚWIĘCEŃ BISKUPICH PASTERZY KOŚCIOŁA WILEŃSKIEGO Z DRUGIEJ ORAZ TRZECIEJ TERCJI XVIII STULECIA
}

\section{ANOINTMENTS AND THE SUCCESSION OF THE EPISCOPAL ORDINATION IN THE SECOND AND THE FOLLOWING THIRD OF THE $18^{\text {TH }}$ CENTURY}

The article concerns the members of the Catholic episcopate connected with the bishops' capital in Vilnius within the second and the following third of the $18^{\text {th }}$ century, during the rule of August III and Stanislaus August. The Vilnius diocese remained then within the borders of the Polish church province whose center was in Gniezno. The materials currently available in Lithuania were at that time unobtainable to the author. He succeeded, however, in examining the sources from Polish and Vatican collections. This enabled the author to present the theme of pastoral anointments in the Vilnius church within the chosen period.

Podjąwszy w poprzednim tomie „Rocznika Teologii Katolickiej” problematykę sakr i sukcesji święceń biskupich pasterzy Kościoła wileńskiego (także białostockiego) z ostatnich dwóch stuleci ${ }^{1}$, zamierzamy ją obecnie kontynuować, obejmując

\footnotetext{
${ }^{1}$ K. R. Prokop, Sukcesja apostolska biskupów i arcybiskupów wileńskich oraz białostockich $w$ XIX $i$ XX stuleciu, „Rocznik Teologii Katolickiej” 4 (2005), s. 165-210. Tytułem uzupełnienia do tamtego opracowania należy wspomnieć, że o konsekracji Nikodema Puzyny i Tadeusza Kundzicza wspomina współczesny wydarzeniom prałat Stanisław Szantyr ([S.] Szantyr, Zbiór wiadomości o Kościele i religii katolickiej w Cesarstwie Rosyjskim, a szczególniej w prowincjach od Polski przyłączonych od czasu pierwszego rozbioru Polski aż do końca panowania cesarza Aleksandra I i początków panowania Mikołaja I, zebrany $z$ pism urzędowych, dokumentów $i$ własnego widzenia, t. 1, Poznań 1843, s. 336 [błędnie pagina 236]), podając iż dopełnił ich w Wilnie sufragan kurlandzki Adam Kossakowski wespół z sufraganem żmudzkim Szymonem Giedroyciem i unickim biskupem Orszy Adrianem Hołownią. Z kolei na daty dzienne tychże dwóch sakr (N. Puzyna - 7 V 1817 r., T. Kundzicz - 10 V tr.) natrafiamy w materiałach do biografii biskupów i administratorów diecezji wileńskiej, zgromadzonych przez ks. Jana Nepomucena Fijałka
} 
analogiczną analizą członków katolickiego episkopatu, związanych ze stolicą biskupią w Wilnie we wcześniejszym okresie. Ponieważ doba porozbiorowa oraz lata II Rzeczypospolitej zostały już omówione pod tym kątem, nasza uwaga kieruje się aktualnie ku przedrozbiorowej Rzeczypospolitej Obojga Narodów, a więc ku czasom, kiedy diecezja wileńska pozostawała w obrębie polskiej prowincji kościelnej, której ośrodek stanowiło świętowojciechowe Gniezno.

Nie jest naszym zamiarem dokonywać $w$ ramach pojedynczego artykułu zaprezentowania stanu wiedzy o sakrach i sukcesji apostolskiej od razu wszystkich biskupów ustanowionych do posługi w diecezji wileńskiej $\mathrm{w}$ dobie staropolskiej. Ich grono było zbyt liczne, by na coś takiego się zdobyć, stąd koniecznym zabiegiem wydaje się wprowadzenie dodatkowych cezur chronologicznych i podzielenie na części zgromadzonego materiału. Tak też obecnie uwagę skoncentrujemy na wieku XVIII - i to nawet nie całym, lecz jego drugiej i trzeciej tercji, odpowiadającym panowaniom królów Augusta III Wettyna i Stanisława Augusta Poniatowskiego. Od razu też w tym miejscu należy wyjaśnić, że o pominięciu w obecnej analizie pierwszej tercji owego ostatniego stulecia dziejów przedrozbiorowej Rzeczypospolitej zadecydował tak istotny aspekt, jak podstawa źródłowa, której zresztą nie będziemy omawiać osobno na wstępie artykułu, jako że stosowne wskazania czytelnik znajdzie przy dalszych wywodach.

W zasadzie niedostępne nam były materiały znajdujące się współcześnie na terenie Litwy, gdzie autor nie miał możliwości przeprowadzenia kwerendy, gdy tymczasem źródła ze zbiorów polskich oraz watykańskich, do których udało się dotrzeć podczas dotychczasowych kwerend piszącemu te słowa, pozwalają na $\mathrm{w}$ miarę pełne (a w każdym razie wolne od poważniejszych luk) przedstawienie tematyki sakr pasterzy Kościoła wileńskiego właśnie dla drugiej i trzeciej tercji XVIII w., natomiast w odniesieniu do pierwszej kwestie wymagające dopiero wyjaśnienia póki co przeważają nad tymi należycie już rozpoznanymi. Wypada tedy żywić nadzieję, że dalsza kwerenda archiwalna, zwłaszcza po objęciu nią zbiorów litewskich oraz rosyjskich, jako że trudna do oszacowania, ale bez wątpienia bardzo duża liczba świadectw do dziejów (również kościelnych) przedrozbiorowej Rzeczypospolitej Obojga

(zob. Katalog rękopisów Biblioteki Polskiej Akademii Nauk w Krakowie. Sygnatury 4716-4796, oprac. B. Sieraczyńska, Z. Solak, J. Staszel, K. Szymurowa, Wrocław - Warszawa - Kraków 1998, s. 34, nr 4751/8 i 4751/10). Jedna więcej informacja o święceniach biskupich Hieronima Strojnowskiego widnieje w wypisach ks. Jana Kurczewskiego $\mathrm{z}$ akt wileńskiej kapituły katedralnej (J. Kurczewski, Kościół zamkowy czyli katedra wileńska $w$ jej dziejowym, liturgicznym, architektonicznym i ekonomicznym rozwoju, t. 3. Streszczenie aktów kapituly wileńskiej, Wilno 1916, s. 421), natomiast obszerna relacja z konsekracji bł. Jerzego Matulewicza zawarta została w ukazującym się od roku 1916 „Dzienniku Wileńskim” („Dziennik Wileński” 3 (1918), nr 280 (z 1 XII 1918 r.), s. 2; nr 282 (z 4 XII 1918 r.), s. 3). 
Narodów trafiła w dobie porozbiorowej do Sankt Petersburga, Moskwy czy innych miejsc na terenie Rosji, pozwoli niejedną jeszcze zagadkę rozwikłać i usunąć przynajmniej część istniejących niewiadomych. Należy jednak liczyć się też z prawdopodobieństwem, że szereg kwestii pozostanie już na zawsze nieodgadnionych, bowiem mnogie wszak zabytki, odnoszące się do historii szeroko rozumianej polskiej państwowości, tudzież cywilizacji, uległy bezpowrotnemu zniszczeniu na skutek czy to nieszczęść losowych, czy też kataklizmów dziejowych. Ten lub inny zabytek piśmiennictwa mógł tymczasem stanowić jedyne świadectwo zawierające wzmiankę na dany temat (w naszym przypadku chodzi konkretnie o sakry biskupie). Oczywiście im wcześniejsza epoka, tym owych współczesnych przekazów jest w ogólności mniej, co siłą rzeczy rzutuje na istniejące możliwości poznawcze. Wydaje się wszakże, że również tematykę konsekracji biskupów wileńskich z XVII i XVI, a nie wykluczone, że nawet i XV w., będzie można omówić w przyszłości w sposób w miarę pełny i tym samym zaistnieje możliwość przyporządkowania owego licznego grona członków katolickiego episkopatu do konkretnych linii sukcesji święceń biskupich. Obecnie uczynimy to $\mathrm{w}$ odniesieniu do hierarchów $\mathrm{z}$ doby panowań Augusta III i Stanisława Augusta.

W momencie zmiany na tronie polskim w roku 1733 posługę $\mathrm{w}$ diecezji wileńskiej sprawowało trzech biskupów. Ordynariuszem był od niedawna Mikołaj Jan Zienkowicz, który $\mathrm{w}$ gronie episkopatu znalazł się jeszcze w roku 1718, natomiast rządy pasterskie w Wilnie objął w roku $1730^{2}$. U jego boku sufraganem wileńskim był tytulariusz Antipatris Jerzy Kazimierz Ancuta, brat niegdysiejszego koadiutora i przez krótko ordynariusza loci Macieja Józefa Ancuty, biskupem ustanowiony za staraniem tegoż ostatniego (wszakże dopiero po jego śmierci) w roku 1723. Nietypowa sytuacja miała natomiast miejsce

${ }^{2} \mathrm{O}$ okolicznościach swego powołania na stolicę biskupią w Wilnie M. J. Zienkowicz pisał w roku 1733 w pierwszej spośród przesłanych do Rzymu w ciągu długoletnich rządów relacji o stanie diecezji: „Post obitum piae memoriae Illustrissimi Caroli Pancerzynski, Serenissimus Rex Poloniarum Augustus Secundus nominaverat primum Illustrissimum Szaniawski, episcopum Chełmensem, quia tamen eum capitulum non elegit, eo quod non fuit patriota Magni Ducatus Lithuaniae, ideo dictus Serenissimus Rex me secundo nominavit" (Relationes status dioecesium in Magno Ducatu Lithuaniae, t. 1. Dioeceses Vilnensis et Samogitiae, P. Rabikauskas (ed.), Romae 1971, s. 118-119). Suplika króla Augusta II, w której monarcha przedstawił Stolicy Apostolskiej jako kandydata na biskupstwo wileńskie M. J. Zienkowicza, nosi datę 15 IV 1730 r. (Hierarchia Catholica medii et recentioris aevi (dalej skrót: HC), t. 6 (1730-1799), cur. R. Ritzler \& P. Sefrin, Patavii 1958, s. 442). 
w przypadku drugiej z istniejących w strukturach Kościoła wileńskiego sufraganii, mianowicie białoruskiej. Zajmujący ją od roku 1722 Bogusław Gosiewski został wprawdzie z początkiem roku 1725 biskupem smoleńskim, ponieważ jednak powierzona mu diecezja, formalnie rezydencjalna, de facto miała charakter tytularny, rzeczonemu hierarsze Stolica Święta zezwoliła zachować nadal funkcję sufragana białoruskiego, która to osobliwa „unia personalna” przetrwała do jego śmierci w roku 1744.

Wszyscy ci trzej hierarchowie weszli do grona episkopatu katolickiego Rzeczypospolitej Obojga Narodów na długo przed rokiem 1733 (w latach 1718-1723), stąd też przy wyznaczonych dla obecnego opracowania ramach chronologicznych ich sakry pozostają poza obszarem naszego zainteresowania (z pojedynczym wyjątkiem, o czym dalej). Jedynie tedy na marginesie wspomnieć można, iż Bogusławowi Gosiewskiemu święceń biskupich udzielić miał ordynariusz warmiński (a niebawem metropolita gnieźnieński i prymas) Teodor Andrzej Potocki (konsekracja ta odbyła się w należącym do misjonarzy św. Wincentego a Paulo kościele pw. Krzyża Św. w Warszawie 3 ), gdy z kolei $\mathrm{w}$ odniesieniu do Jerzego Kazimierza Ancuty nie dysponujemy precyzyjną informacją, kto i gdzie udzielił mu sakry. Zapewne pełni kapłaństwa zamierzał on dostąpić przez posługę swego brata Macieja Józefa Ancuty, ów wszakże zmarł 18 I 1723 r., wkrótce po wstąpieniu na stolicę biskupią w Wilnie, podczas gdy prekonizacja nowego sufragana nastąpiła dopiero 27 IX tr. W tym kontekście można by oczywiście wyrazić przypuszczenie, że święcenia biskupie J. K. Ancuta przyjął w takim razie zapewne $z$ rąk kolejnego ordynariusza wileńskiego, okazuje się ono wszakże nieuprawnione. Oto wzmiankowany w aktach miejscowej kapituły katedralnej pod datą 28 IX 1723 r. jeszcze jako nominat, na sesji kapitulnej 9 XI tr. duchowny ten występuje już jako biskup sufragan, a nie nadal $\mathrm{z}$ tytułem nominata na sufraganię, co pozwala wnioskować, że czy to w ciągu miesiąca października (jeśli już, to raczej pod koniec), czy też w pierwszych dniach listopada 1723 r. odbyła się jego konsekracja. Tymczasem elekcja przez kapitułę wileńską nowego ordynariusza loci, którym został uprzednio desygnowany przez monarchę Karol Piotr Pancerzyński, dotychczasowy biskup smoleński, miała miejsce dopiero 24 III 1724 r., zaś na stosowną decyzję Stolicy Apostolskiej o translacji trzeba było zaczekać jeszcze przez bez mała pół roku

${ }^{3}$ Archivio Segreto Vaticano (dalej skrót: ASV), Archivio Concistoriale, Processus Consistoriales, vol. 111, k. 629r, 631r, 632r; zob. również: K. R. Prokop, Pasterze i rzqdcy diecezji mińskiej, pińskiej i drohiczyńskiej, Drohiczyn 2006, s. 20; por. J. Korytkowski, Arcybiskupi gnieźnieńscy, prymasowie i metropolici polscy od roku 1000 aż do roku 1821 czyli do potączenia arcybiskupstwa gnieźnieńskiego z biskupstwem poznańskim, t. 4, Poznań 1891, s. 452. 


\section{(11 IX tr. $)^{4}$. A zatem święcenia biskupie Jerzy Kazimierz Ancuta przyjął w okresie} trwania wakatu $\mathrm{w}$ diecezji wileńskiej ${ }^{5}$. Pozostaje wreszcie osoba najwcześniej spośród owych trzech hierarchów powołanego do godności pasterskiej Mikołaja Jana Zienkowicza, przy czym ponieważ poczynienie stosownych ustaleń na temat jego sakry będzie nieodzowne dla określenia przynależności do konkretnych linii sukcesji apostolskiej kilku innych biskupów, o których przyjdzie nam pisać w zasadniczej części obecnej analizy, dlatego kwestię tę pozostawimy chwilowo na boku, by powrócić do niej w dalszej części opracowania.

Pierwszym hierarchą, ustanowionym do posługi w Kościele wileńskim w interesującym nas przedziale czasu, tj. po roku 1733, był Józef Julian Stanisław Sapieha, przedstawiciel jednego z najznaczniejszych na Litwie rodów magnackich, z którego zresztą wywodziło się także trzech innych biskupów (najbardziej znany spośród nich to oczywiście kardynał Adam Stefan Sapieha - postać już z XX stulecia). Urodzony w roku 1708 w Gdańsku, nominację biskupią uzyskał w wieku zaledwie 29 lat. Pozostawała ona w związku m.in. z faktem, że 16 IV 1737 r. odszedł do wieczności wspominany już tu sufragan wileński Jerzy

${ }^{4}$ Zob. m.in.: Biblioteka Narodowa w Warszawie, mf A 1936 [= Lietuvos Mokslų Akademijos Biblioteka w Wilnie, sygn. F 9 - 162-166]: Materiały do dziejów historii diecezji wileńskiej z aktów kapituły katedralnej wileńskiej zebrane przez ks. Mamerta Herbuta (dalej skrót: Materiały Mamerta Herbuta), k. 1r-6r (przy translacji z biskupstwa smoleńskiego na wileńskie Karol Piotr Pancerzyński złożył przysięgę na wierność Stolicy Apostolskiej na ręce ordynariusza poznańskiego Jana Joachima Tarły); J. Kurczewski, Kościót zamkowy czyli katedra wileńska, dz. cyt., t. 3, s. 290-292; także: J. I. Kraszewski, Wilno od początków jego do roku 1750, t. 2, Wilno 1840, s. 510 (nr XXVI-XXVII); W. Przyałgowski, Żywoty biskupów wileńskich, t. 3, Sankt Petersburg 1860, s. 122-133; J. Kurczewski, Biskupstwo wileńskie od jego założenia aż do dni obecnych, zawierające dzieje i prace biskupów i duchowieństwa diecezji wileńskiej oraz wykaz kościołów, klasztorów, szkót i zakładów dobroczynnych i społecznych, Wilno 1912, s. 53, 80-81; C. Falkowski, Ancuta Maciej Józef († 1723), biskup wileński, referendarz litewski, w: Polski słownik biograficzny (dalej skrót: PSB), t. 1, Kraków 1935, s. 90-91; T. Długosz, Dzieje diecezji smoleńskiej, Lwów 1937, s. 78 (nr 13); Relationes status dioecesium, dz. cyt., t. 1, s. 12; H. Dymnicka-Wołoszyńska, Pancerzyński KarolPiotr herbu Trzaska (zm. 1729), biskup smoleński, potem wileński, w: PSB, t. 25, Wrocław - Warszawa - Kraków - Gdańsk - Łódź 1980, s. 116-117; T. Krahel, Zarys dziejów (archi)diecezji wileńskiej, „Studia Teologiczne. Białystok - Drohiczyn - Łomża" 5-6 (1987-1988), s. 28 (nr 26-27); P. Nitecki, Biskupi Kościoła $w$ Polsce $w$ latach 965-1999. Stownik biograficzny, Warszawa 2000, kol. 6, 332-333; V. Petkus, Vilniaus vyskupai Lietuvos istorijoje, Vilnius 2002, s. 493-497, 785-786, 855.

${ }^{5}$ Zob. nadto: Diarium Collegii Societatis Jesu ab anno 1710 ad anni 1723 septembrem exclusive. Vilniaus jèzuitų kolegijos dienoraštis 1710-1721 metai, I. Katilienè (ed.), Vilnius 2004, s. 598/599-604/ 605. Kronika ta kończy się na 31 VIII 1723 r. (obejmuje zaś okres od 1 IV 1710 r.), stąd nie znajdujemy tam informacji o sakrze J. K. Ancuty, która nastąpiła wszak dopiero w ciągu października lub w początkach listopada $1723 \mathrm{r}$. (już za to $\mathrm{w}$ odniesieniu do daty $23 \mathrm{I}$ tr. jest on tam wspominany jako „nominatus suffraganeus Vilnensis” - tamże, s. 598/599). Ze źródła tego dowiadujemy się także, że w dniach 7-19 IV 1723 r. przebywał w Wilnie ordynariusz włocławski Krzysztof Antoni Szembek (tamże, s. 606/607-608/609), jednakże dla wyżej wskazanej przyczyny nie mógł on udzielić wówczas sakry desygnowanemu na miejscową sufraganię duchownemu, skoro ten nie był jeszcze prekonizowany przez Stolicę Apostolską. 
Kazimierz Ancuta ${ }^{6}$. Tego samego dnia ordynariusz loci Mikołaj Jan Zienkowicz desygnował na sufraganię właśnie młodego Sapiehę, jak o tym zresztą ów ostatni sam wspomina w prowadzonym $\mathrm{w}$ tamtych latach diariuszu? ${ }^{7}$. W rzeczywistości jednak jeszcze w roku poprzednim, dzięki wstawiennictwu kanclerza wielkiego litewskiego Jana Fryderyka Sapiehy, jego krewniak desygnowany został przez króla Augusta III koadiutorem z prawem następstwa przy biskupie Wilna (monarsza suplika do Stolicy Apostolskiej nosi datę 4 VII 1736 r.), co też usankcjonowała stosowna elekcja ze strony miejscowej kapituły katedralnej (16 X tr.). Ostatecznie 12 VI 1737 r. papież Klemens XIII udzielił prekonizacji Sapieże, który - właśnie jako koadiutor posuniętego w latach pasterza Kościoła wileńskiego - otrzymał tytularną stolicę biskupią Diocezarei (Diocesarea).

O zapadłej w Rzymie decyzji nominat dowiedział się w miesiąc później, tj. 12 VII tr. (przy tej okazji zanotował w przywołanym już diariuszu, że jego prekonizacja miała miejsce jakoby jeszcze $8 \mathrm{VI}$ ), zaś stosowne dokumenty Stolicy Świętej (bulle papieskie) nadeszły do Wilna i znalazły się w jego rękach 2 VIII $^{8}$. Tym samym mogły obecnie rozpocząć się właściwe przygotowania do konsekracji Józefa Juliana Sapiehy, który o udzielenie święceń biskupich poprosił ordynariusza loci, swego koadiuta. Z kolei na współkonsekratorów zaproszeni zostali biskupiżmudzki Jozafat Karp (nota bene sam konsekrowany zaledwiekilka miesięcy wcześniej w wileńskiej katedrze przez M. J. Zienkowicza) oraz smoleński Bogusław Gosiewski, który to - jak wcześniej wspomniano - sprawował zarazem obowiązki sufragana białoruskiego. Pomiędzy tymi dwoma hierarchami doszło wszakże wówczas do sporu o precedencję, bo jakkolwiek diecezja żmudzka w cursus honorum biskupstw Rzeczypospolitej Obojga Narodów znajdowała się wyżej aniżeli smoleńska, to jednak B. Gosiewski uważał, że z racji starszeństwa sakry przysługuje mu pierwszeństwo przed J. Karpiem. Kiedy kontrowersja ta rozstrzygnięta została nie po myśli Gosiewskiego, w przeddzień aktu święceń biskupich tytulariusza Diocezarei wycofał się on z przyjętego uprzednio na

${ }^{6}$ „Kurier Polski” 1737, nr XXI, s. [4]; J. Kurczewski, Kościół zamkowy czyli katedra wileńska, dz. cyt., t. 3, s. 313 (gdzie wszakże data 16 V 1737 r.); nadto: J. Wolff, Senatorowie i dygnitarze Wielkiego Księstwa Litewskiego 1386-1795, Kraków 1885, s. 309; C. Falkowski, Ancuta Jerzy Kazimierz († 1737), biskup sufragan wileński, referendarz litewski, w: PSB, t. 1, s. 90.

${ }^{7}$ Biblioteka Narodowa w Warszawie, sygn. BOZ 941: Diarium vitae Illustrissimi, Excellentissimi ac Reverendissimi Domini, Domini Josephi Juliani comitis Sapieha, episcopi Dioecesariensis, coadiutoris Vilnensis, manu propria conscriptum et gesta varia memoranda intra decursum vitac ipsius adnotata (dalej skrót: Diarium vitae Josephi Juliani Sapieha), s. 244-245 („Die 16 Aprilis A.D. 1737 Ancuta, suff raganeus Vilnensis, phtysi consumptus, lente moritur (...). Eadem die episcopus [Vilnensis] mihi suff raganeatum appromisit").

${ }^{8}$ Tamże, s. 251; zob. także akta procesu informacyjnego, poprzedzającego wyniesienie J. J. Sapiehy do godności biskupiej: ASV, Archivio Concistoriale, Processus Consistoriales, vol. 123, k. 555r-574v. 
siebie zobowiązania bycia współkonsekratorem Sapiehy. Na szczęście ów krok biskupa smoleńskiego nie wywołał poważniejszych komplikacji, wraz bowiem $\mathrm{z}$ ordynariuszem żmudzkim przybył do Wilna na mającą się odbyć uroczystość jego sufragan Aleksander Horain. On też zajął miejsce urażonego hierarchy jako drugi współkonsekrator (w innym przypadku być może zaszłaby konieczność przesunięcia terminu ceremonii). A zatem mimo tamtego niezbyt miłego incydentu sakra Józefa Juliana Sapiehy odbyła się bez przeszkód w niedzielę 1 IX 1737 r. w katedrze w Wilnie, przy czym głównym konsekratorem był Mikołaj Jan Zienkowicz, współkonsekratorami Jozafat Karp i Aleksander Horain. Obok nich nie zabrakło też w świątyni katedralnej wspominanego wyżej biskupa smoleńskiego, który jakkolwiek powodowany ambicjami zrezygnował z funkcji współkonsekratora, to jednak najwyraźniej nie poczuł się aż do tego stopnia urażonym, by w ogóle nie pojawić się na tamtym uroczystym akcie9.

Jakkolwiek tytulariusz diocezarejski, którego sakrze oraz towarzyszącym jej okolicznościom poświęciliśmy powyżej nieco więcej uwagi, do grona episkopatu należał przez ponad 14 lat, to jednak nie dane mu było przeżyć swego koadiuta i objąć rządów w Kościele wileńskim. Zaważyła na tym przedwczesna śmierć J. J. Sapiehy w wieku 46 lat, która nastąpiła 4 XII 1754 r. ${ }^{10}$ Zwolnioną przez jego zgon sufraganię w Wilnie objął wówczas o wiele starszy, bowiem zbliżający się do 70. roku życia Antoni Józef Żółkowski, który stosowną prowizję papieską uzyskał 21 VII 1755 r. W tamtym momencie biskupem był on wszakże już od ponad dekady, jako że jemu właśnie przypadła w roku 1744 sufragania

${ }^{9}$ Diarium vitae Josephi Juliani Sapieha, s. 253-255 (zwł. s. 254); „Kurier Polski” 1737, nr XXXVI, s. [3]-[4]; także: Z. Zielińska, Sapieha Józef Stanistaw (1708-1754), biskup koadiutor wileński, referendarz wielki duchowny litewski, w: PSB, t. 35, Warszawa - Kraków 1994, s. 24; por. J. Kurczewski, Kościót zamkowy czyli katedra wileńska, dz. cyt., t. 3, s. 313.

${ }^{10}$ Biblioteka Naukowa Księży Jezuitów w Krakowie, rkp b. sygn. (fotokopia) [= Lietuvos Valstybinis Istorijos Archyvas w Wilnie, sygn. F 1135 ap 20]: Diarium Collegii Academici Vilnensis Societatis Jesu 1752-1766 (dalej skrót: Diarium Collegii Academici Vilnensis), k. 44v; „Kurier Polski” 1754, nr LXXVI, s. [1]-[2]; Rękopism X. Bagińskiego, dominikanina prowincji litewskiej (1747-1784 r.), wyd. E. Tyszkiewicz, Wilno 1864, s. 27; J. Kurczewski, Kościót zamkowy czyli katedra wileńska, dz. cyt., t. 3, s. 339; nadto: J. Wolff, Senatorowie i dygnitarze, dz. cyt., s. 310; J. Kurczewski, Kościół zamkowy czyli katedra wileńska, dz. cyt., t. 1, Wilno 1908, s. 323 (nr 18); Z. Szostkiewicz, Katalog biskupów obrządku łacińskiego przedrozbiorowej Polski, w: Sacrum Poloniae Millenium. Rozprawy - Szkice - Materialy historyczne, t. 1, Rzym 1954, s. 551; HC, t. 6, 442; Urzędnicy centralni i dygnitarze Wielkiego Księstwa Litewskiego XIV-XVIII wieku. Spisy, H. Lulewicz i A. Rachuba (oprac.) (Urzędnicy dawnej Rzeczypospolitej XII-XVIII wieku. Spisy, t. 11), Kórnik 1994, s. 172 (nr 1355), 238; Z. Zielińska, Sapieha Józef Stanisław, dz. cyt., s. 24-27 (toż w: Dom Sapieżyński, E. Sapieha (oprac.), Warszawa 1995, s. 449-454); P. Nitecki, Biskupi Kościoła, dz. cyt., kol. 393; V. Petkus, Vilniaus vyskupai, dz. cyt., s. 855-856; Wileński stownik biograficzny, H. Dubowik i L. J. Malinowski (red.), (Encyklopedia Ziemi Wileńskiej, t. 1), Bydgoszcz 2002, s. 356. 
białoruska po zmarłym 23 VI tr. Bogusławie Gosiewskim ${ }^{11}$. Będący poprzednio archidiakonem białoruskim, kanonikiem wileńskim i smoleńskim oraz proboszczem stwołowickim, 58-letni A. J. Żółkowski prekonizowany został 7 XII 1744 r. przez papieża Benedykta XIV tytulariuszem Alalii - z przeznaczeniem do posługi $\mathrm{w}$ diecezji wileńskiej właśnie $\mathrm{w}$ charakterze sufragana białoruskiego ${ }^{12}$. Jego konsekracja odbyła się też w katedrze w Wilnie w niedzielę 21 II 1745 r., zaś dopełnił jej ordynariusz loci Mikołaj Jan Zienkowicz wespół z biskupami: żmudzkim Antonim Dominikiem Tyszkiewiczem i inflanckim (wendeńskim) Józefem Dominikiem Puzyną ${ }^{13}$. Zastanowienie wzbudzić może fakt, że jednym ze współkonsekratorów nie był koadiutor wileński Józef Julian Sapieha, jak jednak można wywnioskować w oparciu o zapiski z jego diariusza, hierarcha ów w tamtym momencie przebywał w ogóle poza Wilnem (na powrót widzimy go tam dopiero 10 IV 1745 r., a już 13 VII tr. ponownie wyjechał), w czego następstwie w rzeczonym źródle brak nawet jakiejkolwiek wzmianki o sakrze tytularnego biskupa alalieńskiego ${ }^{14}$.

Kiedy w roku 1755 Antoni Józef Żółkowski uzyskał przeniesienie z sufraganii białoruskiej na wileńską, nowym sufraganem dla Białorusi został w jego miejsce bratanek zasiadającego na stolicy biskupiej w Wilnie pasterza, 46-letni Tomasz Ignacy Zienkowicz, dotychczasowy prałat kustosz kapituły ${ }^{15}$. Prekonizowany 21 VII 1755 r. przez papieża Benedykta XIV tytulariuszem Areopolis (od razu zatem w tym samym dniu, w którym miała miejsce translacja A.J. Żółkowskiego), święcenia biskupie przyjął w niedzielę 9 XI 1755 r. w świątyni katedralnej w Wilnie. Obowiązków konsekratora swego krewniaka nie podjął się wszakże -

${ }^{11}$ Zob. Diarium vitae Josephi Juliani Sapieha, s. 388-389; J. Kurczewski, Kościót zamkowy czyli katedra wileńska, dz. cyt., t. 3, s. 323; także: T. Długosz, Dzieje diecezji smoleńskiej, s. 78 (nr 14); E. Rostworowski, Gosiewski Bogusław Korwin herbu Ślepowron (ok. 1660-1744), biskup smoleniski, w: PSB, t. 8, Wrocław - Kraków - Warszawa 1959-1960, s. 340-342; P. Nitecki, Biskupi Kościoła, dz. cyt., kol. 126-127; V. Petkus, Vilniaus vyskupai, dz. cyt., s. 803, 837-838; K. R. Prokop, Pasterzei rzadcy, dz. cyt., s. 20 .

${ }_{12}$ Zob. akta procesu informacyjnego: ASV, Archivio Concistoriale, Processus Consistoriales, vol. 131, k. 1r-11v.

${ }^{13}$ ASV, Archivio Concistoriale, Processus Consistoriales, vol. 131, k. 4v (,iuramentum ante munus consecrationis”); „Kurier Polski” 1745, nr CCCCXXXI, s. [2]; Materiały Mamerta Herbuta, k. 61r; J. Kurczewski, Kościót zamkowy czyli katedra wileńska, dz. cyt., t. 3, s. 324; K. R. Prokop, Pasterze i rządcy, dz. cyt., s. 20.

${ }^{14}$ Diarium vitae Josephi Juliani Sapieha, s. 406-410.

15 Zob. Encyklopedia powszechna [Orgelbranda], t. 28, Warszawa 1868, s. 610-611 (F. M. Sobieszczański); J. Wolff, Senalorowie i dygnitarze, dz. cyt., s. 280; J. Kurczewski, Kościt zamkowy czyli katedra wileńska, dz. cyt., t. 1, s. 323-324 (nr 20); t. 3, s. 323; tenże, Biskupstwo wileńskie, dz. cyt., s. 85; Z. Szostkiewicz, Katalog biskupów, dz.cyt., s. 597; HC, t. 6, s. 97-98; Relationes stalus dioecesium, dz. cyt., t. 1, s. 15; Urzędnicy centralni i dygnitarze, dz. cyt., s. 131 (nr 975), 181 (nr 1444), 253; T. Kasabuła, Ignacy Massalski, dz. cyt., s. 146-150; P. Nitecki, Biskupi Kościoła, dz. cyt., kol. 516; V. Petkus, Vilniaus vyskupai, dz. cyt., s. 839; Wileński słownik biograficzny, s. 443. 
jak można by było oczekiwać - ordynariusz loci Mikołaj Jan Zienkowicz, bowiem liczył sobie wówczas 85 lat i tego rodzaju trud przekraczał jego siły. Wyręczył go w tej funkcji wspomniany już wcześniej biskup żmudzki Antoni Dominik Tyszkiewicz, u boku którego wystąpili w charakterze współkonsekratorów dwaj sufragani: wileński Antoni Józef Żółkowski oraz żmudzki Aleksander Horain ${ }^{16}$. Godność sufragana białoruskiego Tomasz Ignacy Zienkowicz piastował zresztą niezbyt długo, bowiem w siedem i pół roku później, kiedy 19 I 1763 r. dobiegło kresu życie biskupa Antoniego Józefa Żółkowskiego ${ }^{17}$, dane było tytulariuszowi areopolitańskiemu pójść w jego ślady i uzyskać translację z sufraganii białoruskiej na wileńską (od tamtej starszą metryką i przede wszystkim lepiej uposażoną, a tym samym bardziej eksponowaną). Stosowną decyzję w owej materii podjął wszakże już nowy pasterz Kościoła wileńskiego, jako że stryj Tomasza Ignacego Zienkowicza, ordynariusz Mikołaj Jan Zienkowicz, odszedł do wieczności niemal dokładnie w rok przed A. J. Żółkowskim - 23 I 1762 r. ${ }^{18}$

Jego następcą jeszcze $\mathrm{z}$ końcem stycznia 1762 r. król August III desygnował biskupa żmudzkiego Antoniego Dominika Tyszkiewicza. Kiedy wszakże ów niespodziewanie zmarł 30 I tr., w drugim tygodniu lutego na stolicę biskupią

16 ASV, Archivio Concistoriale, Processus Consistoriales, vol. 151, k. 552r (por. k. 556r); Diarium Collegii Academici Vilnensis, k. 58r; „Kurier Polski” 1755, nr CXXII, s. [2]-[3]; Materiały Mamerta Herbuta, k. 101v; J. Kurczewski, Kościót zamkowy czyli katedra wileńska, dz. cyt., t. 3, s. 340; K. R. Prokop, Pasterze i rzadcy, dz. cyt., s. 20-21; por. T. Kasabuła, Ignacy Massalski, biskup wileński, Lublin 1998, s. 147 (który to autor podaje błędną datę 2 XI 1755 r.).

${ }^{17}$ Zob. m.in.: Archiwum Prowincji OO. Bernardynów w Krakowie, sygn. S-Wi-4: Hystoria domus seu acta particularia seu diarium Conventus Custodialis Vilensis Ordinis Minorum Obs. A 1761 inchoatum (dalej skrót: Hystoria Conventus Custodialis Vilnensis), s. 50; Diarium Collegii Academici Vilnensis, k. 188r; Pamiętniki Józefa Kossakowskiego, biskupa inflanckiego, 1738-1788, wyd. A. Darowski, Warszawa 1891, s. 41; J. Kurczewski, Kościót zamkowy czyli katedra wileńska, dz. cyt., t. 3, s. 345; także: J. Kurczewski, Biskupstwo wileńskie, dz. cyt., s. 85; tenże, Kościół zamkowy czyli katedra wileńska, dz. cyt., t. 1, s. 323 (nr 19); J. Poplatek, Wykaz alumnów Seminarium Papieskiego w Wilnie 1582-1773, „Ateneum Wileńskie" 14 (1936), s. 267 (nr 417); Z. Szostkiewicz, Katalog biskupów, dz. cyt., s. 597; HC, t. 6, s. 71; Relationes status dioecesium, dz. cyt., t. 1, s. 15; T. Kasabuła, Ignacy Massalski, dz. cyt., s. 146; P. Nitecki, Biskupi Kościoła, dz. cyt., kol. 522; V. Petkus, Vilniaus vyskupai, dz. cyt., s. 839; Wileński słownik biograficzny, dz. cyt., s. 448.

${ }^{18}$ Zob. m.in.: Hystoria Conventus Custodialis Vilnensis, s. 30-31; Diarium Collegii Academici Vilnensis, k. 156v; „Kurier Warszawski” 1762, nr 9 (z 30 I 1762 r.), s. [1]; Rękopism X. Bagińskiego, dz. cyt., s. 35-36; Pamiętniki Marcina Matuszewicza, kasztelana brzeskiego-litewskiego, 1714-1765, wyd. A. Pawiński, t. 3, Warszawa 1876, s. 157-158; J. Kurczewski, Kościół zamkowy czyli katedra wileńska, dz. cyt., t. 3, s. 344; także: J. I. Kraszewski, Wilno od początków jego, dz. cyt., t. 2, s. 510-511 (nr XXVIII); W. Przyałgowski, Żywoty biskupów, dz. cyt., t. 3, s. 133-169; Encyklopedia powszechna [Orgelbranda], t. 28, s. 610 (F. M. Sobieszczański); J. Kurczewski, Kościół zamkowy czyli katedra wileńska, dz. cyt., t. 1, s. 316 (nr 27); tenże, Biskupstwo wileńskie, dz. cyt., s. 53-55; Z. Szostkiewicz, Katalog biskupów, dz. cyt., s. 596-597; HC, t. 6, s. 442; Relationes status dioecesium, dz. cyt., t. 1, s. 12, 231; T. Krahel, Zarys dziejów (archi)diecezji, dz. cyt., s. 28 (nr 28); V. Petkus, Vilniaus vyskupai, dz. cyt., s. 501-511; Wileński słownik biograficzny, s. 443. 
w Wilnie przedstawiony został z kolei dotychczasowy referendarz duchowny Wielkiego Księstwa Litewskiego Ignacy Jakub Massalski (suplika królewska z 13 II tr.), który prekonizację papieską uzyskał (ze strony Klemensa XIII) 29 III tr. ${ }^{19}$ Warto $\mathrm{w}$ tym miejscu dodać, że był to pierwszy, od bez mała wieku, pasterz Kościoła wileńskiego, który w momencie powierzenia mu tej eksponowanej stolicy nie należał jeszcze do grona episkopatu, lecz dopiero teraz przyjąć miał sakrę (poprzedni to Mikołaj Stefan Pac - jeśli nie brać w rachubę będącego wpierw koadiutorem Macieja Józefa Ancuty, który zresztą zaraz u progu rządów zmarł). Odbyła się ona zatem ze szczególnie uroczystą oprawą w niedzielę 2 V 1762 r. w Wilnie, w katedrze św. Stanisława, przy czym z jakichś względów mający przyjąć święcenia biskupie duchowny nie zatroszczył się o to, by ów akt zaszczycił swą obecnością pasterz którejkolwiek innej spośród ówczesnych diecezji Rzeczypospolitej Obojga Narodów. W konsekwencji całą trójkę konsekratorów tworzyli sufragani, mianowicie wileński Antoni Józef Żółkowski, białoruski Tomasz Ignacy Zienkowicz i żmudzki Aleksander Horain. Temu ostatniemu, jako spośród nich najstarszemu sakrą (niespełna dwa miesiące wcześniej obchodził jej trzydziestą rocznicę), przypadły obowiązki głównego konsekratora, natomiast dwaj pozostali byli współkonsekratorami ${ }^{20}$. W dwa tygodnie później, 16 V 1762 r., I. J. Massalski dopełnił uroczystego ingresu²1,

${ }^{19}$ Zob. akta procesu informacyjnego: ASV, Archivio Concistoriale, Processus Consistoriales, vol. 150, k. 594r-602v; także: „Kurier Warszawski” 1762, nr 13 (z 13 II 1762 r.), s. [1]; HC, t. 6, s. 442.

${ }^{20}$ Hystoria Conventus Custodialis Vilnensis, s. 35; Diarium Collegii Academici Vilnensis, k. 168r-v; „Kurier Warszawski” 1762, nr 35 (z 1 V 1762 r.), s. [2], nr 39 (z 15 V 1762 r.), s. [2]-[3]; Pamiętniki Marcina Matuszewicza, dz. cyt., t. 3, s. 172; Pamiętniki Józefa Kossakowskiego, dz. cyt., s. 35 (z błędną datą 3 V 1761 r.); także: W. Przyałgowski, Żywoly biskupów, dz. cyt., t. 3, s. 173; J. Kurczewski, Biskupstwo wileńskie, dz. cyt., s. 55; I. Szybiak, Massalski Ignacy Jakub herbu własnego (1726-1794), biskup wileński, działacz polityczny, prezes Komisji Edukacji Narodowej, w: PSB, t. 20, Wrocław - Warszawa - Kraków - Gdańsk 1975, s. 135 (gdzie jako datę sakry błędnie podano 27 VII 1762 r., którą przytacza również J. M. Giżycki, Wiadomości o dominikanach prowincji litewskiej, t. 1, Kraków 1917, s. 274); T. Kasabuła, Ignacy Massalski, dz. cyt., s. 92-93 (tamże również przyp. 252); por. Materiały Mamerta Herbuta, k. 117r. Zestawienie drukowanych panegiryków ogłoszonych z okazji konsekracji I. J. Massalskiego oraz późniejszych kolejnych jej rocznic podaje: K. Estreicher, Bibliografia polska, t. 22, Kraków 1908, s. 213-215. Nota bene okolicznościowe kazanie podczas tamtego aktu święceń biskupich wygłosił (i następnie wydał drukiem) ówczesny prepozyt wileński i archidiakon żmudzki Jan Stefan Giedroyć, już wkrótce powołany przez nowego ordynariusza loci na sufraganię białoruską (zob. K. Estreicher, Bibliografia polska, t. 17, Kraków 1899, s. 134; T. Turkowski, Giedroyć Jan Stefan (zm. 1803), biskup inflancki, następnie żmudzki, w: PSB, t. 7, Kraków 1948-1958, s. 427).

${ }^{21}$ Hystoria Conventus Custodialis Vilnensis, s. 36; Diarium Collegii Academici Vilnensis, k. 170rv; „Kurier Warszawski” 1762, nr 41 (z 22 V 1762 r.), s. [2]; Rękopism X. Bagińskiego, dz. cyt., s. 36; por. J. Kurczewski, Kościót zamkowy czyli katedra wileńska, dz. cyt., t. 3, s. 344. Pierwotnie data ingresu I. J. Massalskiego wyznaczona została na 9 V 1762 r., wszakże na prośbę wojewody wileńskiego Michała Kazimierza Radziwiłła, który pragnął wakcietym osobiście uczestniczyć, została ona przesunięta na tydzień później, tj. właśnie na 16 V tr. (Hystoria Conventus Custodialis Vilnensis, s. 36). Rzeczony M. K. Radzi- 
zaś po upływie kolejnego miesiąca jemu samemu dane było po raz pierwszy udzielić święceń biskupich, jako że wespół z Antonim Józefem Żółkowskim i Aleksandrem Horainem konsekrował 13 VI tr. w katedrze w Wilnie nowego ordynariusza żmudzkiego Jana Dominika Łopacińskiego ${ }^{22}$.

Kolejnym hierarchą, który otrzymał sakrę właśnie z rąk Ignacego Jakuba Massalskiego, był nowy sufragan białoruski Jan Stefan Giedroyć. Od razu w tym samym dniu, w którym Tomasz Zienkowicz uzyskał translację z sufraganii białoruskiej na wileńską, tj. 22 VIII 1763 r., otrzymał on ze strony papieża Klemensa XIII prekonizację na biskupa tytularnego Uranopolis (Verinopolis) ${ }^{23}$, jednakże $\mathrm{z}$ nieznanych nam przyczyn $\mathrm{z}$ dopełnieniem konsekracji J. S. Giedroycia zwlekano bez mała pół roku. W doprowadzonych dla roku 1763 tylko do dnia $27 \mathrm{X}$ wypisach ks. Mamerta Herbuta $\mathrm{z}$ wileńskich akt kapitulnych ów nowy członek episkopatu określany jest do samego końca wskazanego okresu mianem „nominata”, „nominata sufragana” czy też „nominata biskupa”24. Po tym w rzeczonym źródle następuje luka aż do 12 III 1764 r., pod którą to datą tytulariusz Uranopolis wspominany jest jako biskup sufragan, a nie nominat, już zatem posiadał wówczas sakrę ${ }^{25}$. Otrzymał ją dokładnie miesiąc wcześniej, w niedzielę 12 II 1764 r., o czym dowiadujemy się z kolei z diariusza Akademii Wileńskiej (Diarium Collegii Academici Societatis Jesu). Uroczysty ów akt miał miejsce w murach świątyni katedralnej w Wilnie, zaś jako główny konsekrator wystąpił pasterz diecezji, biskup I. J. Masalski. W oparciu o dostępny nam materiał nie jesteśmy natomiast $\mathrm{w}$ stanie jednoznacznie określić, którzy inni

wiłł zmarł zresztą zaledwie $22 \mathrm{~V}$ tr. - na skutek przeziębienia się podczas owych uroczystości ingresowych (H. Dymnicka-Wołoszyńska, Radziwiłł Michał Kazimierz zwany Rybeńko herbu Trąby (1702-1762), hetman wielki litewski, wojewoda wileński, ordynat nieświeski i otycki, w: PSB, t. 30, Wrocław - Warszawa - Kraków - Gdańsk - Łódź 1987, s. 305); zob. także: 'T. Kasabuła, Ignacy Massalski, dz. cyt., s. 94-96.

${ }^{22}$ Hystoria Conventus Custodialis Vilnensis, s. 41; Diarium Collegii Academici Vilnensis, k. 175r; „Kurier Warszawski” 1762, nr 51 (z 26 VI 1762 r.), s. [1]-[2]; M. Wołłonczewski, Biskupstwo żmujdzkie, Kraków 1898, s. 102.

${ }^{23}$ Zob. akta procesu informacyjnego: ASV, Archivio Concistoriale, Processus Consistoriales, vol. 151, k. 560r-575v; nadto: Encyklopedia powszechna [Orgelbranda], t. 9, Warszawa 1862, s. 724-726 (J. Bartoszewicz); J. Kurczewski, Kościół zamkowy czyli katedra wileńska, dz. cyt., t. 1, s. 326 (nr 11); tenże, Biskupstwo wileńskie, dz. cyt., s. 85; T. Turkowski, Giedroyć Jan Stefan, dz. cyt., s. 427-418; Z. Szostkiewicz, Katalog biskupów, dz. cyt., s. 455; HC, t. 6, s. 438; Relationes status dioecesium, dz. cyt., t. 1, s. 15, 230, 558; T. Kasabuła, Ignacy Massalski, dz. cyt., s. 154-156; P. Nitecki, Biskupi Kościoła, dz. cyt., kol. 115-116; V. Petkus, Vilniaus vyskupai, dz. cyt., s. 839; Wileński słownik biograficzny, s. 85.

${ }^{24}$ Zob. Materiały Mamerta Herbuta, k. 120r-122v (sesje odbyte w dniach 28 i 30 IX, 3, 4, 18, 19 i 27 X 1763 r.).

${ }^{25}$ Tamże, k. 123v. Z kolei w ówczesnej kronice bernardynów wileńskich o J. S. Giedroyciu, jako biskupie, czytamy dopiero w odniesieniu do daty 21 IX 1764 r., kiedy to udzielił on święceń klerykom z tegoż zakonu (natomiast 26 IX tr. przewodniczył w Wilnie uroczystym obchodom wspomnienia liturgicznego bł. Jozafata Kuncewicza). Hystoria Conventus Custodialis Vilnensis, s. 93. 
hierarchowie obeceni byli na tamtej ceremonii i przyjęli na siebie obowiązki współkonsekratorów (jednym był zapewne T. I. Zienkowicz) ${ }^{26}$.

Podjęcie funkcji sufragana białoruskiego stanowiło poniekąd tylko epizod w karierze kościelnej Jana Stefana Giedroycia, już bowiem w momencie, kiedy przyjmował święcenia biskupie, trwały starania o powierzenie mu rządów w na wpoły tytularnej diecezji inflanckiej (wendeńskiej), z której właśnie w roku 1763 odszedł do Włocławka biskup Antoni Kazimierz Ostrowski (wcześniej będący koadiutorem włocławskim). Upłynęło jednak półtora roku nim sprawy udało się pomyślnie sfinalizować, dopiero bowiem 22 IV $1765 \mathrm{r}$. J. S. Giedroyć prekonizowany został na biskupstwo inflanckie. To oznaczało z kolei konieczność ponownego obsadzenia sufraganii białoruskiej, jednakże i w tym przypadku sprawa uległa dłuższej zwłoce, co pozostawało w ścisłym związku z faktem, że ordynariusz loci postanowił funkcję tę powierzyć duchownemu wywodzącemu się z szeregów kleru zakonnego i tym samym nie należącemu do grona wileńskiej kapituły katedralnej. Ta ostatnia próbowała na wszelkie sposoby odwieść pasterza diecezji od powziętego zamysłu ${ }^{27}$, a widząc jego nieustępliwość w owej materii, podjęła nawet działania mające przyczynić się do utrącenia kandydatury na gruncie rzymskim.

Poczynania kanoników z Wilna spowodowały wprawdzie pewne perturbacje, ostatecznie jednak Stolica Apostolska przychyliła się do prośby biskupa Massalskiego i udzieliła prekonizacji desygnowanemu przezeń na sufraganię białoruską zakonnikowi. Był to Tadeusz Benedykt (w zakonie Feliks) Towiański, członek Zakonu Braci Mniejszych Konwentualnych i w latach 1760-1763 prowincjał litewski, którego papież Klemens XIII prekonizował 1 XII 1766 r. tytulariuszem karpazjeńskim (Carpasia) ${ }^{28}$. Nowy sufragan dla

${ }^{26}$ ASV, Archivio Concistoriale, Processus Consistoriales, vol. 153, k. 288r, 289r, vol. 176, k. 245r.; Diarium Collegii Academici Vilnensis, k. 213v (zob. także: k. 211r, gdzie pod datą 8 I 1764 r. J. S. Giedroyć wspominany jest jeszcze jako „suffraganeus Albae Russiae nominatus"); por. K. R. Prokop, Pasterze i rzadcy, dz. cyt., s. 21.

${ }^{27}$ Przy tej okazji dowiadujemy się z akt kapitulnych (sesja 1 X 1764 r.), żew omawianym czasie wileńska kapituła „miała w swym gronie pięciu biskupów, a szóstego w diecezji, biskupa Ludwika Riaocura, biskupa Ptolemaidy i proboszcza słuckiego" (J. Kurczewski, Kościół zamkowy czyli katedra wileńska, dz. cyt., t. 3, s. 347). Ów ostatni, syn Jakuba i Franciszki Riaocurów, urodzony 21 II 1702 r. i ochrzczony 27 IV tr. w kolegiacie św. Jana Chrzciciela w Warszawie, był w latach 1749-1777 sufraganem łuckim. Konsekrowany został 1 VI 1749 r. w kościele pw. Krzyża Św. w Warszawie przez ordynariusza płockiego Antoniego Sebastiana Dembowskiego oraz sufraganów gnieźnieńskiego Krzysztofa Dobińskiego i płockiego Marcina Załuskiego („Kurier Polski” 1749, nr DCLXIII, s. [1]-[2]).

${ }^{28}$ Zob. akta procesu informacyjnego: ASV, Archivio Concistoriale, Processus Consistoriales, vol. 154, k. 115r-129v; nadto: Pamiętniki Józefa Kossakowskiego, dz. cyt., s. 42, 55-56; J. Kurczewski, Kościót zamkowy czyli katedra wileńska, dz. cyt., t. 1, s. 326 (nr 12); tenże, Biskupstwo wileńskie, dz. cyt., s. 85; Z. Szostkiewicz, Katalog biskupów, dz. cyt., s. 573; HC, t. 6, s. 148; Relationes status dioecesium, dz. cyt., t. 1, s. 15; T. Kasabuła, Ignacy Massalski, dz. cyt., s. 156-158; P. Nitecki, Biskupi Kościoła, dz. cyt., kol. 452; 
Białorusi sakrę przyjął bardzo rychło, przy czym - zapewne właśnie ze względu na konflikt $\mathrm{z}$ wileńską kapitułą (być może odegrały tu pewną rolę również $\mathrm{i}$ inne względy) - odbyła się ona nie w stolicy Wielkiego Księstwa Litewskiego, lecz w Warszawie. Uroczystość ta miała miejsce w niedzielę 4 I 1767 r. w warszawskim kościele franciszkanów konwentualnych, noszącym wezwanie Stygmatów św. Franciszka Serafickiego, o którym to fakcie dowiadujemy się z ówczesnej prasy $^{29}$. Nie wynika z niej jednakowoż, przez czyją posługę dostąpił Towiański pełni kapłaństwa, tzn. kto był jego głównym konsekratorem, a którzy biskupi współkonsekratorami. Nie dowiadujemy się tego również z innych dostępnych nam źródeł, przy czym w szczególności zaskakuje fakt, że brak jakiejkolwiek wzmianki o tej sakrze w aktach (kronice) warszawskiego klasztoru Zakonu Braci Mniejszych Konwentualnych, mimo że - jak już wspomniano - właśnie w tamtejszej świątyni rzeczona uroczystość miała miejsce ${ }^{30}$.

W jakiś czas po konsekracji biskup Towiański powrócił do Wilna, gdzie znajdujemy go w dniu 12 VI 1767 r. dokonującego konsekracji tamtejszej świątyni macierzystego zakonu ${ }^{31}$. Później jednak rezydował najczęściej na Witebszczyźnie, posiadał tam bowiem bogato uposażone probostwo $\mathrm{w}$ Kubliczach, zaś w sąsiednim Lepelu zorganizował $\mathrm{z}$ polecenia biskupa Massalskiego osobny konsystorz białoruski i stanął na jego czele jako oficjał. Mimo też późniejszej rezygnacji z sufraganii, co nastąpiło jakoby zaraz w roku 1772, z ziemiami tymi pozostał związany do końca życia, przy czym śmierć zaskoczyła go 19 VI 1782 roku w Połocku (wówczas już pod zaborem rosyjskim), dokąd udał się właśnie dla poratowania zdrowia. Pochowany został w konsekrowanej przezeń świątyni franciszkanów konwentualnych w Wilnie, przy czym uroczystości pogrzebowe odbyły się dopiero w dniach 27-28 II $1783 \mathrm{r}^{32} \mathrm{Nie}$ od rzeczy będzie nadmienić w tym miejscu, że w ostatnich latach życia miał on u swego boku wywodzącego

V. Petkus, Vilniaus vyskupai, dz. cyt., s. 839-840; K. R. Prokop, Polscy biskupi franciszkańscy. Stownik biograficzny, Kraków 2003, s. 150-154; tenże, Pasterze i rządcy, dz. cyt., s. 21-22.

${ }_{29}$ „Wiadomości Warszawskie” 1767, nr 2 (z 7 I 1767 r.) - Suplement, s. [4]; także: K. R. Prokop, Polscy biskupi franciszkańscy, dz. cyt., s. 152; tenże, Pasterze i rzadcy, dz. cyt., s. 21.

${ }^{30}$ Biblioteka Narodowa w Warszawie, mf 9099 [= Archiwum Klasztoru OO. Franciszkanów Konwentualnych w Warszawie, rkp b. sygn.]: Acta conventus Varsaviensis Ordinis [Fratrum] Minorum Conventualium [ab] anno Domini 1741. Według informacji udzielonej autorowi przez o. Romana Aleksandra Soczewkę (Archiwum OO. Franciszkanów Prowincji Matki Bożej Niepokalanej), ów zmikrofilmowany w roku 1954 rękopis, któremu wszakże nie została nadana sygnatura archiwalna, przekazano z klasztoru w Warszawie - wraz z pozostałymi zbiorami archiwalnymi - do Instytutu Franciszkańskiego w Łodzi-Łagiewnikach, gdzie też obecnie winien się znajdować.

${ }^{31}$ Hystoria Conventus Custodialis Vilnensis, s. 198-199; także: K. R. Prokop, Polscy biskupi franciszkańscy, dz. cyt., s. 152.

32 „Gazeta Warszawska” 1782, nr 55 (z 20 VII 1782 r.), s. [2]; Hystoria Conventus Custodialis Vilnensis, s. 314; Rękopism X. Bagińskiego, dz. cyt., s. 122; zob. także wyżej literaturę wskazaną w przyp. 28; nadto: Stownik geograficzny Królestwa Polskiego i innych krajów słowiańskich, t. 4, Warszawa 1883, s. 833. 
się z jego macierzystego zakonu kapelana Piotra Stankiewicza, który odegrać miał w przyszłości niejednoznaczną rolę w dziejach Kościoła katolickiego pod panowaniem rosyjskim, będąc - po sekularyzacji - członkiem tzw. Justiz-Kollegium, prałatem scholastykiem kapituły katedralnej w Mińsku i kandydatem na koadiutora ordynariusza kamienieckiego ${ }^{33}$. W owym późniejszym okresie P. Stankiewicz zaliczał się też do najbliższych współpracowników metropolity mohylowskiego Stanisława Siestrzeńcewicza, któremu to hierarsze przyjdzie nam obecnie poświęcić nieco uwagi, bowiem on właśnie - i to niemal u samego progu swej kariery kościelnej - zastąpił biskupa Towiańskiego na funkcji sufragana białoruskiego.

Został nim z woli ordynariusza Massalskiego i przy poparciu dworu królewskiego w roku 1773, otrzymując 12 VII tr. od papieża Klemensa XIV prekonizację na biskupa tytularnego Mallus ${ }^{34}$. Zapewniwszy S. Siestrzeńcewiczowi infułę biskupią, $\mathrm{z}$ jakichś względów pasterz Kościoła wileńskiego, który zaledwie pięć lat wcześniej wprowadził swego protegowanego do grona miejscowej kapituły katedralnej, nie podjął się udzielenia mu sakry, w którym to względzie wyręczył go były pasterz diecezji smoleńskiej Jerzy Mikołaj Hilzen (z powierzonego mu biskupstwa zrezygnował jeszcze w roku 1763). Rzeczona sakra odbyła się w Wilnie, dokąd Stanisław Siestrzeńcewicz przybył prosto z Warszawy, gdzie bawił poprzednio (zastanawiające, że od razu tam nie przyjął święceń biskupich). Jako jej data w literaturze przedmiotu zgodnie podawana jest niedziela $3 \times 1773 \mathrm{r}^{35}$ (nota bene dokładnie w tym samym dniu, tyle że właśnie w Warszawie, dopełniona została konsekracja na biskupa płockiego królewskiego brata Michała Jerzego Poniatowskiego, też zresztą

${ }^{33}$ Zob. [S.] Szantyr, Zbiór wiadomości o Kościele, dz. cyt., t. 1, s. 156-157, 227-231, 256, 269-272; także: K. R. Prokop, Pasterze i rządcy, dz. cyt., s. 43-44.

${ }^{34}$ Zob. akta procesu informacyjnego: ASV, Archivio Concistoriale, Processus Consistoriales, vol. $165, \mathrm{k} .25 \mathrm{r}-38 \mathrm{v}$ (nota bene jednym z zeznających w tymże procesie był biskup T. B. F. Towiański); takie: A. A. Brumanis, Aux origines de la hiérarchie latin en Russie. Mgr Stanislas Siestrzencewicz-Bohusz, premier archevêque-métropolitain de Mohilev, (1731-1826), Louvain 1968, s. 29-32.

${ }^{35}$ M.in.: M. Loret, Kościót katolicki a Katarzyna II 1772-1784 (Monografie w zakresie dziejów nowożytnych, t. 12), Kraków 1910, s. 51; M. Godlewski, Siestrzeńcewicz-Bohusz Stanisław Jan herbu Strzała, pierwszy metropolita wszystkich kościołów rzymsko-katolickich w Imperium Rosyjskim, w: Podręczna encyklopedia kościelna, t. 35/36, Warszawa 1912, s. 245; J. Wasilewski, Arcybiskupi $i$ administratorowie archidiecezji mohylowskiej, Pińsk 1930, s. 4; A. A. Brumanis, Aux origines de la hiérarchie latin en Russie, dz. cyt., s. 32; Č. Sipovič, The Diocese of Minsk. Its Origin, Extent and Hierarchy, "The Journal of Byelorussian Studies" 6 (1970), t. 2, nr 1, s. 180; R. W. Wołoszyński, Siestrzeńcewicz (Bohusz-Siestrzeńcewicz, Siestrzeńcewicz-Bohusz) Stanistaw Jan herbu Strzała (1731-1826), metropolita Kościoła rzymskokatolickiego w Rosji, autor prac historycznych, w: PSB, t. 37, Warszawa - Kraków 19961997, s. 376; T. Kasabuła, Ignacy Massalski, dz. cyt., s. 161; [D. Bączkowski, J. Żyskar], Nasze Kościoły, t. 1. Archidiecezja mohylowska, cz. 1, Mohylowszczyzna, Warszawa 2001 [reprint], s. 10; V. Petkus, Vilniaus vyskupai, dz. cyt., s. 840; K. R. Prokop, Pasterze i rzadcy, dz. cyt., s. 23. 
prekonizowanego 12 VII tr.). Tym niemniej w katalogach (wykazach) arcypasterzy Kościoła mohylowskiego, zamieszczanych w kolejnych wydaniach schematyzmu (elenchusa) tejże archidiecezji (inna rzecz, że dopiero pod koniec wieku XIX i w początkach następnego stulecia), interesujący nas fakt przypisany został do daty 1 IX 1773 r. $^{36}$ Aktualnie trudno nam wskazać na źródło tej rozbieżności, wszakże fakt, że w aktach wileńskiej kapituły katedralnej czytamy pod datą $4 \times 1773$ r. o gratulacjach ze strony tegoż kolegium kanoniczego pod adresem Siestrzeńcewicza, swego wszak konfratra, na okoliczność - jak streszcza odnośną zapiskę J. Kurczewski - „jego wyniesienia [sic] na biskupa malleńskiego dnia wczorajszego [podkr. K.R.P.]" ${ }^{37}$ (niewątpliwie chodzi właśnie o sakrę, choć w podstawie widniał zapewne wprawdzie wieloznaczny, ale odnoszony również do aktu sakry termin evectio [in episcopum]), zdaje się nie pozostawiać wątpliwości, że jednak dzień $3 \mathrm{X}$ to rzeczywisty termin konsekracji tytulariusza Mallus (zresztą 1 IX przypadł w roku 1773 w środę, podczas gdy jako termin udzielania święceń biskupich obierano albo niedzielę, albo też święto kościelne lub wspomnienie liturgiczne któregoś $\mathrm{z}$ apostołów, takim zaś dzień ów nie był). Lukę w naszej wiedzy stanowi natomiast kwestia współkonsekratorów, którzy wystąpili podczas tamtego aktu (być może obowiązku tego podjęli się Towiański i Zienkowicz).

Stanisław Siestrzeńcewicz był ostatnim sufraganem białoruskim w dziejach diecezji wileńskiej. W owym zresztą czasie, w konsekwencji I rozbioru Rzeczypospolitej Obojga Narodów, większa część Białorusi znalazła się pod berłem rosyjskim i właśnie $\mathrm{z}$ ustanowienia władającej $\mathrm{w}$ Rosji cesarzowej Katarzyny II tytulariusz Mallus otrzymał 23 V 1774 r. niekanoniczny tytuł biskupa białoruskiego, a w siedem i pół roku później, w analogicznym trybie, przypadła mu godność arcybiskupa mohylowskiego (28 I 1782 r.). Dopiero u schyłku roku 1783 przebywający od niedawna w Sankt Petersburgu legat papieski Giovanni Andrea Archetti usankcjonował te powzięte w sposób sprzeczny z przyjętymi w Kościele katolickim procedurami decyzje, a tym samym de facto już od dawna nie będący sufraganem ordynariusza wileńskiego S. Siestrzeńcewicz również de iure uznany został za pasterza odrębnego Kościoła partykularnego, czego

\footnotetext{
${ }^{36}$ Np.: Directorium Divini Officii et Missarum pro Archidioecesi Mohiloviensi nec non pro ecclesiis Minscensibus in annum Domini 1893, [Petropoli] 1892, s. 285; Directorium Divini Officii et Missarum pro Archidioecesi Mohiloviensi in annum Domini 1902, Petropoli 1901, s. 214; Directorium Divini Officii et Missarum pro Archidioecesi Mohiloviensi in annum Domini bissextilem 1904, Petropoli 1904, s. 218. $\mathrm{W}$ oparciu właśnie o schematyzmy archidiecezji mohylowskiej datę tę przyjął również B. Kumor, Ustrój $i$ organizacja Kościoła polskiego w okresie niewoli narodowej (1772-1918), Kraków 1980, s. 38 (tabela: Metropolici mohylowscy 1783-1917).

${ }^{37}$ J. Kurczewski, Kościół zamkowy czyli katedra wileńska, dz. cyt., t. 3, s. 360.
} 
uwieńczeniem był dopełniony 29 I 1784 r. w stolicy Cesarstwa Rosyjskiego akt przekazania mu przez wspomnianego legata papieskiego paliusza metropolity. Tym samym dzieje sufraganii białoruskiej dobiegły kresu ${ }^{38}$.

W kierowanej przez biskupa Ignacego Jakuba Massalskiego diecezji po roku 1774 pozostał de facto tylko jeden sufragan - wileński. Było to bez wątpienia zbyt mało jak na potrzeby obejmującego wciąż jeszcze bardzo rozległe terytoria Kościoła lokalnego. Ordynariusz loci podjął zatem działania, by doprowadzić do zmiany stanu rzeczy w owym względzie, co też w krótkim czasie udało mu się osiągnąć - i to zgoła $\mathrm{z}$ naddatkiem. Zapewne od samego początku zamyśliwał on o utworzeniu nowej sufraganii okręgowej, ponieważ jednak z jednej strony wiązało się to $\mathrm{z}$ koniecznością zapewnienia jej należytego uposażenia, z drugiej zaś stosowne procedury w Kurii Rzymskiej mogły okazać się dość przewlekłe (i kosztochłonne), w pierwszej kolejności I. J. Massalski wystarał się o mianowanie do posługi $\mathrm{w}$ Kościele wileńskim biskupa tytularnego nie przypisanego do którejkolwiek z fundowanych sufraganii. Owym biskupem pomocniczym, nie będącym sufraganem, został dominikanin Walenty Wołczacki (Wołłczacki), którego papież Klemens XIV prekonizował 6 VI 1774 r., a więc trzy i pół miesiąca przed swą śmiercią, tytulariuszem Tamasus ${ }^{39}$. Sakra tegoż zakonnika odbyła się w niedzielę 21 VIII 1774 r. w Warszawie w kościele jego macierzystej wspólnoty zakonnej, tj. dominikanów, przy czym obowiązków głównego

${ }^{38}$ Ogólnie do biografii S. Siestrzeńcewicza zob. m.in.: M. Loret, Kościół katolicki a Katarzyna II, dz. cyt., passim (zwł. s. 47 i n.); J. Kurczewski, Kościót zamkowy czyli katedra wileńska, dz. cyt., t. 1, s. 326 (nr 13); tenże, Biskupstwo wileńskie, dz. cyt., s. 85-86; M. Godlewski, Siestrzeńcewicz-Bohusz Stanisław Jan, dz. cyt., s. 242-257; J. Wasilewski, Arcybiskupi i administratorowie, dz. cyt., s. 1-6; HC, t. 6, s. 274; A. A. Brumanis, Aux origines de la hiérarchie latin en Russie, dz. cyt., passim; Č. Sipovič, The Diocese of Minsk, dz. cyt., s. 179-181; Relationes status dioecesium, dz. cyt., t. 1, s. 16, 370; B. Kumor, Ustrój i organizac ja, dz. cyt., passim (m.in. s. 17, 23); H. E. Wyczawski, Siestrzeńcewicz Bohusz Stanisław Jan herbu Strzała (1731-1826), metropolita mohylowski, autor pamiętników, w: Słownik polskich teologów katolickich (dalej skrót: SPTK), t. 4, H. E. Wyczawski (red.), Warszawa 1983, s. 79-82; R. W. Wołoszyński, Siestrzeńcewicz (Bohusz-Siestrzeńcewicz, Siestrzeńcewicz-Bohusz) Stanisław Jan, dz. cyt., s. 375-380; T. Kasabuła, Ignacy Massalski, dz. cyt., s. 159-163; [D. Bączkowski, J. Żyskar], Nasze Kościoty, t. 1, cz. 1, s. 10-17; P. Nitecki, Biskupi Kościoła, dz. cyt., kol. 402; V. Petkus, Vilniaus vyskupai, dz. cyt., s. 804-806, 840; K. R. Prokop, Pasterze i rzadcy, dz. cyt., s. 23-26; zob. także: „Gazeta Warszawska” 1782, nr 23 (z 20 III 1782 r.) - Suplement, s. [1]-[2]; 1783, nr 93 (z 19 XI 1783 r.), s. [1]. Wspomnieć można w tym miejscu, że jedyny biskup, odnośnie do którego mamy pewność, iż konsekrował go właśnie S. Siestrzeńcewicz, to sufragan zadźwiński (inflancki) Jerzy Powsławski, przy czym jednym z jego współkonsekratorów był $\mathrm{z}$ kolei T. B. F. Towiański (mowa o wydarzeniu $\mathrm{z}$ roku 1781).

${ }^{39}$ Zob. akta procesu informacjnego: ASV, Archivio Concistoriale, Processus Consistoriales, vol. 166, k. 312r-326v; por. Rękopism X. Bagińskiego, dz. cyt., s. 64 („za protekcją księżnej Teodory z Sołtanów Sapieżyny, wojewodziny mścisławskiej, od Najjaśniejszego Króla Stanisława Augusta wywyższony na biskupstwo tamasseńskie"); nadto: J. Kurczewski, Biskupstwo wileńskie, dz. cyt., s. 97; J. M. Giżycki, Wiadomości o dominikanach, dz. cyt., t. 1, s. 256; HC, t. 6, s. 391; V. Petkus, Vilniaus vyskupai, dz. cyt., s. 790, 803-804, 869; odnośnie do rodu Wołczackich: J. Ciechanowicz, Rody rycerskie Wielkiego Księstwa Litewskiego, t. 5, Rzeszów 2001, s. 394-395. 
konsekratora podjął się ówczesny nuncjusz apostolski w Rzeczypospolitej Obojga Narodów, arcybiskup Giuseppe Garampi, natomiast współkonsekratorami byli ordynariusze: chełmski Antoni Onufry Okęcki i smoleński Gabriel Wodzyński

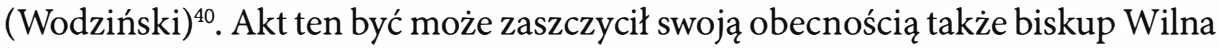
I. J. Massalski, który dzień wcześniej (tj. 20 VIII) przybył do Warszawy ${ }^{11}$.

W niewiele ponad pół roku później doszło z kolei do kanonicznego utworzenia przez Stolicę Apostolską w diecezji wileńskiej owej nowej sufraganii, która otrzymała miano trockiej, oraz powierzenia jej desygnowanemu na tę funkcję prałatowi kustoszowi Józefowi Kazimierzowi Kossakowskiemu ${ }^{42}$. Nowy papież Pius VI, w niespełna miesiąc po swym wyborze, prekonizował go 13 III 1775 r. biskupem tytularnym Cinny ${ }^{43}$, po czym po półtora miesiącu odbyła się sakra nominata. I tym razem na jej miejsce obrano Warszawę, wszakże nie kościół dominikanów (jak w przypadku W. Wołczackiego), lecz misjonarzy-lazarystów, noszący wezwanie Krzyża Świętego (dzisiejsza bazylika). Jako główny konsekrator wystąpił też wówczas - z dala od swej stolicy - ordynariusz wileński Ignacy Jakub Massalski (jego obecność tam wiązała się z trwającymi od 6 do 19 III tr. obradami sejmu), natomiast współkonsekratorami byli: ordynariusz chełmski Antoni Onufry Okęcki oraz koadiutor włocławski Józef Ignacy Rybiński. Uroczysty ów akt miał miejsce w niedzielę 30 IV 1775 r. $^{44}$

40 „Gazeta Warszawska” 1774, nr 68 (z 24 VII 1774 r.), s. [2]; „Gazety Wileńskie” 1774, nr 36 (z 3 IX 1774 r.), s. [2]; Rękopism X. Bagińskiego, dz. cyt., s. 64. Odnośnie do osoby głównego konsekratora, który później zaliczony został w poczet Kolegium Kardynalskiego, zob. D. Vanysacker, Cardinal Giuseppe Garampi (1725-1792) - an Enlightened Ultramontane, Bruzelles/Brussel - Rome 1995; por. M. Borkowska, Dekret w niebieskim ferowany parlamencie. Wybór testamentów z XVII-XVIII wieku, Kraków 1984, s. 164-165, 167-172. Z zamieszczonego tamże testamentu wspomnianej w poprzednim przypisie księżnej Teodory z Sołtanów Sapieżyny ( $\mathrm{z}$ daty: Janów, 8 VIII 1774 r.), której W. Wołczacki był domowym teologiem, dowiadujemy się, iż otrzymał on od niej „daną w gotowiźnie sumę na sakrę (...) do trzydziestu kilku tysięcy złotych wynoszącą", obecnie wieczyście mu darowaną przez testatorkę (s. 169). Wydawczyni źródła błędnie wszakże informuje w dodanym komentarzu, że „Wołczacki sakrę otrzymał jednak dopiero w 11 lat później, w roku 1785" (s. 169, przyp. 124). Zresztą wspomniana w tekście rozporządzenia testamentalnego „sakra" bynajmniej nie odnosi się w tym przypadku do obrzędu święceń biskupich, lecz oznacza bullę papieską, zawierajacą nadanie godnosci biskupiej i zezwolenie na przyjęcie konsekracji.

${ }^{41}$ Zob. „Gazety Wileńskie” 1774, nr 35 (z 27 VIII 1774 r.), s. [3].

${ }^{42} \mathrm{~W}$ kronice bernardynów wileńskich już pod datą 7 XII 1774 r. J. K. Kossakowski wspomniany jest jako „nominatus suff raganeus Trocensis” (Hystoria Conventus Custodialis Vilnensis, s. 269).

${ }^{43}$ Akta procesu informacyjnego: ASV, Archivio Concistotriale, Processus Consistoriales, vol. 167, k. 287r-300v; zob. nadto: B. Kumor, Ustrój i organizacja, dz. cyt., s. 215.

${ }^{44}$ ASV, Archivio Concistoriale, Processus Consistoriales, vol. 193, k. 390v; "Gazeta Warszawska” 1775, nr 36 (z 6 V 1775 r.), s. [1]; „Gazety Wileńskie” 1775, nr 20 (z 13 V 1775 r.), s. [3]; Pamiętniki Józefa Kossakowskiego, dz. cyt., s. 83 (gdzie J. K. Kossakowski stwierdza w odniesieniu do osoby I. J. Massalskiego, iż „sam się oświadczył być moim konsekratorem”); Rękopism X. Bagińskiego, dz. cyt., s. 67; także: A. Zahorski, Kossakowski Józef Kazimierz herbu Ślepowron, przydomek Korwin (1738-1794), biskup inflancki, pisarz, targowiczanin, w: Polski słownik biograficzny, t. 14, Wrocław - Warszawa - Kraków 1968-1969, s. 268; T. Kasabuła, Ignacy Massalski, dz. cyt., s. 164. 
Obecnie zatem I. J. Massalski miał już trzech „regularnych” biskupów pomocniczych, których zadaniem było wspomaganie go w posługach pontyfikalnych w rozległej diecezji, obok których wszakże udzielać się tu mogli także i inni hierarchowie, jak chociażby „emerytowany” sufragan białoruski Tadeusz Benedykt (Feliks) Towiański, czy też tytulariusz meniteński Józef Prószyński vel Pruszyński. W Żywotach biskupów wileńskich W. Przyałgowski, który nie znał nawet imienia tego ostatniego hierarchy, nie wiadomo na jakiej podstawie twierdzi, że był on kanonikiem wileńskim, odnosząc tę informację do roku 1798 i wyrażając zarazem domysł, że być może biskup ów „spodziewał się [wówczas] zasiąść na tronie pasterskim w Wilnie"45. Przynależność J. Prószyńskiego do grona miejscowej kapituły katedralnej nie znajduje tymczasem potwierdzenia w innych opracowaniach $^{46}, \mathrm{z}$ pewnością zaś błędne jest pisanie o tytulariuszu meniteńskim w odniesieniu do roku 1798, jako że zmarł on jeszcze 4 XI 1790 r. $^{47}$

Faktem natomiast pozostaje, że aż do śmierci duchowny ten był związany $\mathrm{z}$ diecezją wileńską (jego życie dobiegło kresu w należących doń dobrach dziedzinych Nowy Dwór na Mińszczyźnie), z której zresztą pochodził, jako że urodził się 10 X 1710 r. właśnie na Mińszczyźnie. W Wilnie też wstąpił w roku 1726 do zakonu jezuitów, który jednak po siedmiu latach opuścił (1733), poświęcając się - jako osoba świecka - karierze politycznej (był m.in. podkomorzym mińskim i marszałkiem Trybunału Wielkiego Księstwa Litewskiego). W wieku 52 lat powrócił wprawdzie w szeregi Towarzystwa Jezusowego (1772), już jednak po roku nastąpiła kasata zakonu, zaś Prószyński znalazł się $\mathrm{w}$ szeregach kleru diecezjalnego (święcenia wyższe otrzymał w czerwcu 1773 r.). Ciesząc się - dzięki swej niegdysiejszej działalności - poparciem zarówno ze strony dworu królewskiego, jak i pasterza Kościoła wileńskiego, po upływie stosunkowo niedługiego czasu został przedstawiony Stolicy Apostolskiej jako kandydat do godności biskupiej i 17 II 1777 r. uzyskał prekonizację na tytulariusza Mennith. Jego konsekracja odbyła się 21 IX tr. w kościele pw. Krzyża Św. w Warszawie, należącym do misjonarzy-lazarystów. Dopełnił jej ówczesny nuncjusz apostolski w Rzeczypospolitej Obojga Narodów, arcybiskup tytularny Chalcedonu Giovanni Andrea Archetti, wespół z biskupami: inflanckim (wendeńskim) Janem Stefanem Giedroyciem i smoleńskim Gabrielem Wodzińskim (Wodzyńskim) ${ }^{48}$. Od tego momentu Józef

${ }^{45}$ W. Przyałgowski, Żywoty biskupów wileńskich, t. 3, Wilno 1860, s. 213.

${ }^{46}$ Por. zwłaszcza: J. Kurczewski, Kościót zamkowy czyli katedra wileńska, dz. cyt., t. 1, s. 332-333.

${ }^{47}$ "Gazeta Warszawska" 1790, nr 93 (z 20 XI 1790 r.) - Suplement, s. [1]-[2].

${ }^{48}$ ASV, Archivio Concistoriale, Iuramenta, vol. 7, k. 146r-147v; „Gazeta Warszawska” 1777, nr 77 (z 24 IX 1777 r.), s. [1]; HC, t. 6, s. 286. 
Prószyński mógł zatem udzielać się pontyfikalnie w rodzinnej diecezji przez trzynaście lat, czyli do końca życia ${ }^{49}$.

$\mathrm{Na}$ kilka miesięcy przed śmiercią wspomnianego wcześniej biskupa Towiańskiego, Kościołowi wileńskiemu przybył drugi „emeryt” w infule, jako że 19 XI 1781 r. ustąpił z miejscowej sufraganii posunięty już w latach biskup Tomasz Ignacy Zienkowicz (zmarł 9 XII 1790 r.) ${ }^{50}$. Ponieważ mniej więcej w tym samym czasie z kolei Józef Kazimierz Kossakowski uzyskał translację na rezydencjalne biskupstwo inflanckie (17 IX 1781 r.), niemal naraz zwolniły się sufraganie wileńska i trocka. W tych okolicznościach obie też zostały obsadzone równocześnie i $\mathrm{w}$ dniu 23 IX 1782 r. papież Pius VI prekonizował dwóch nowych członków katolickiego episkopatu, którzy mieli podjąć posługę u boku Ignacego Jakuba Massalskiego. Mianowicie tytulariuszem Belle został wówczas Piotr Samson Toczyłowski, przeznaczony na sufragana wileńskiego, natomiast tytularną stolicę Thespiae otrzymał Franciszek Gzowski, desygnowany na sufragana trockiego ${ }^{51}$. Obaj oni przyjęli też wspólnie sakrę dnia 29 XII 1782 r. w niedzielę w Oktawie Bożego Narodzenia - z rąk ordynariusza loci, zaś obowiązku współkonsekratorów podjęli się biskupi Tomasz Ignacy Zienkowicz i Walenty Wołczacki (Wołłczacki). Miejscem owego podniosłego aktu było Wilno, tym wszakże razem nie katedra św. Stanisława, lecz pojezuicki kościół akademicki (parafialny) św. Jana Chrzciciela i św. Jana Ewangelisty ${ }^{52}$.

Przed rychłym już końcem istnienia Rzeczypospolitej Obojga Narodów odbyła się konsekracja jednego jeszcze biskupa pomocniczego, ustanowionego do posługi w Kościele wileńskim. I tym razem - podobnie, jak w przypadku W. Wołczackiego oraz J. Prószyńskiego - nie był to „regularny” sufragan, lecz obdarzony infułą eks-zakonnik, który wspomagać miał ordynariusza

${ }^{49}$ Zob. nadto: Encyklopedia wiedzy o jezuitach na ziemiach Polski i Litwy 1564-1995, L. Grzebień (oprac.), Kraków 2004, s. 545.

${ }^{50}$ Archiwum Prowincji OO. Bernardynów w Krakowie, sygn. S-Wi-5: Liber 2dus historiae domus P. P. Bernardinorum in conventu Vilnensi describi inchoatus anno 1783 [1783-1794] (dalej skrót: Liber secundus historiae domus Patrum Bernardinorum), s. 313-314; J. Kurczewski, Kościół zamkowy czyli katedra wileńska, dz. cyt., t. 3, s. 387; także: HC, t. 6, s. 97-98.

${ }^{51}$ Akta procesów informacyjnych w: ASV, Archivio Concistoriale, Processus Consistoriales, vol. 182, k. 40r-55v, 400r-413v; nadto: T. Kasabuła, Ignacy Massalski, dz. cyt., s. 150-153, 167-169; P. Nitecki, Biskupi Kościoła, dz. cyt., kol. 138, 448.

${ }^{52}$ ASV, Archivio Concistoriale, Iuramenta, vol. 8, k. 89r-90r; Hystoria Conventus Custodialis Vilnensis, s. 312; „Gazeta Warszawska” 1783, nr 5 (z 15 I 1783 r.) - Suplement, s. [1]; „Gazety Wileńskie” 1783, nr 1 (z 4 I 1783 r.), s. [1]-[2]; HC, t. 6, s. 119; także: J. Kurczewski, Kościót zamkowy czyli katedra wileńska, dz. cyt., t. 1, s. 324 (nr 21), 326-327 (nr 2); Z. Szostkiewicz, Katalog biskupów, dz. cyt., s. 451, 570; HC, t. 6, s. 119, 403; Relationes status dioecesium, dz. cyt., s. 15-16; T. Kasabuła, Ignacy Massalski, dz. cyt., s. 152, 169; P. Nitecki, Biskupi Kościoła, dz. cyt., kol. 138, 448; V. Petkus, Vilniaus vyskupai, dz. cyt., s. 842, 857-858; Wileński stownik biograficzny, s. 407. 
jako tytulariusz nie przypisany do którejkolwiek $\mathrm{z}$ istniejących $\mathrm{w}$ diecezji sufraganii. Mowa o prekonizowanym 24 VII 1786 r. przez papieża Piusa VI tytulariuszem Troas 38-letnim Mikołaju Bykowskim, do niedawna jeszcze członku Zakonu Kaznodziejskiego (dominikaninie), którego szeregi opuścił on - niewątpliwie w związku z szykującą się już nominacją biskupią - zaledwie w roku 1785 (indultum saecularisationis uzyskał 14 XI tr., a już w miesiąc później, 20 XII, otrzymał probostwo słuckie). Duchowny ten święcenia biskupie przyjął w niedzielę 5 XI 1786 r. w kościele sakramentek w Warszawie, przy czym w jego przypadku obowiązków głównego konsekratora podjął się ordynariusz inflancki (niegdysiejszy zaś sufragan trocki) Józef Kazimierz Kossakowski, mając za współkonsekratorów koadiutora smoleńskiego Adama Naruszewicza oraz sufragana żmudzkiego Antonina Malinowskiego (także wywodzącego się spośród duchowych synów św. Dominika) ${ }^{53}$. Owa nominacja M. Bykowskiego, który do końca życia zachował probostwo słuckie i po utworzeniu w roku 1798 biskupstwa mińskiego przede wszystkim w tej właśnie diecezji się udzielał, reprezentując ją również w nowo utworzonym Rzymsko-Katolickim Kolegium Duchownym w Sankt Petersburgu i zarazem stojąc na czele kapituły katedralnej w Mińsku jako prepozyt, poniekąd zapełnić miała ubytek w stanie liczebnym episkopatu wileńskiego, spowodowany przedwczesną śmiercią Franciszka Gzowskiego, zmarłego 21 XII $1785 \mathrm{r}^{54}$ Zastanawia wszakże, dlaczego nie doszło od razu wtenczas do obsadzenia zwolnionej przez jego śmierć sufraganii trockiej, która wakować miała od tego momentu przez całą dekadę ${ }^{55}$.

W pięćlat po konsekracji tytulariusza Troas, dnia 19 XII 1791 r., udzielający mu niegdyś sakry biskup Inflant J. K. Kossakowski został potwierdzony przez Stolicę Świętą w funkcji koadiutora ordynariusza wileńskiego, na którą I. J. Massalski przybrał go jeszcze w listopadzie 1790 r. (konsensus ze strony króla Stanisława Augusta nastąpił dopiero jednak 19 IV 1791 r.). Następcą swego

53 „Gazeta Warszawska” 1786, nr 89 (z 8 XI 1786 r.), s. [4] (oraz kontynuacja opisu w „Dodatku do Gazety Warszawskiej” nr 89); zob. nadto: [S.] Szantyr, Zbiór wiadomości o Kościele, dz. cyt., t. 1, s. 139; HC, t. 6, s. 418; P. Nitecki, Biskupi Kościoła, dz. cyt., kol. 46; K. R. Prokop, Pasterze i rzqdcy, dz. cyt., s. 41, 62; także: J. Ciechanowicz, Rody rycerskie, dz. cyt., t. 1, Rzeszów 2001, s. 175-180.

${ }^{54}$ Liber secundus historiae domus Patrum Bernardinorum, s. 107 [k. 54r]; J. Kurczewski, Kościót zamkowy czyli katedra wileńska, dz. cyt., t. 3, s. 382.

${ }^{55}$ T. Kasabuła (Ignacy Massalski, dz. cyt., s. 169-170) uważa, że powodem, dla którego „po śmierci [F. Gzowskiego] sufragania trocka pozostała nieobsadzona na wiele lat (...), był - oprócz skomplikowanej sytuacji politycznej kraju - brak należytego uposażenia". Warto też dodać w tym kontekście, iż. po roku 1786 rezydował w Wilnie również biskup tytularny Tripolis Józef Leon Łopaciński, który zrezygnował wówczas z sufraganii żmudzkiej, w późniejszym natomiast czasie osiadł na Witebszczyźnie; zob. m.in.: M. Wołłonczewski, Biskupstwo żmujdzkie, s. 105; J. Kurczewski, Biskupstwo wileńskie, dz. cyt., s. 97; [D. Bączkowski, J. Żyskar], Nasze Kościoły, t. 1. Archidiecezja mohylowska, cz. 3. Witebszczyzna, Warszawa 2001 [reprint], s. 435-436. 
koadiuta nigdy on wszakże nie został, obu ich bowiem połączyła tragiczna śmierć w dniach insurekcji kościuszkowskiej (maj/czerwiec 1794 r.) ${ }^{56}$. Po tamtych tragicznych wydarzeniach oraz rychłym upadku Rzeczypospolitej Obojga Narodów, stolica biskupia w Wilnie, wówczas włączonym już w obręb Cesarstwa Rosyjskiego, pozostawała nieobsadzona aż po schyłek roku 1798. W okresie tym diecezją zarządzał obrany 1 XII 1794 r. wikariuszem kapitulnym Dawid Zygmunt Pilchowski, eks-jezuita i prałat (koadiutor dziekana) miejscowej kapituły, którego biskup I. J. Massalski jeszcze w drugiej połowie roku 1793 desygnował na sufragana wileńskiego, co pozostawało $\mathrm{w}$ związku z zaistniałą rezygnacją z owej sufraganii Piotra Samsona Toczyłowskiego. Burzliwe wydarzenia lat 90. XVIII stulecia sprawiły, że na papieską prekonizację przyszło mu czekać do roku 1795. Mianowicie 1 VI tr. papież Pius VI wyniósł go do godności biskupa tytularnego Echinus, którego to samego dnia prekonizowany został również nowy sufragan inflancki Adam Kossakowski (jako tytulariusz Limyra) ${ }^{57}$.

O tym drugim wspominamy tu bynajmniej nieprzypadkowo, kiedy bowiem na mocy dekretu delegata apostolskiego arcybiskupa Lorenzo Litty $z$ dnia 8 VIII 1798 r. biskupstwo wileńskie zyskało zmienione granice i w jego obrębie znalazła się również część zniesionej wówczas diecezji inflanckiej (reszta włączona została

${ }^{56}$ M.in.: W. Przyałgowski, Żywoty biskupów, dz. cyt., t. 3, s. 169-205; S. K. Kossakowski, Monografie historyczno-genealogiczne niektórych rodzin polskich, t. 1, Warszawa 1876, s. 170-172; J. Wolff, Senatorowie i dygnitarze, dz. cyt., s. 280, 282, 310; J. Kurczewski, Kościót zamkowy czyli katedra wileńska, dz. cyt., t. 1, s. 317 (nr 28), 326 (nr 1); tenże, Biskupstwo wileńskie, dz. cyt., s. 55-63; J. Fijałek, Kościót rzymsko-katolicki w Inflantach pod władztwem polskim (1582-1772/95), „Kwartalnik Teologiczny Wileński” 1 (1923), z. 2, s. 196; Z. Szostkiewicz, Katalog biskupów, dz. cyt., s. 490, 512; HC, t. 6, s. 442; Relationes status dioecesium, dz. cyt., t. 1, s. 12, 14, 16, 558; I. Szybiak, Massalski Ignacy Jakub, dz. cyt., s. 135-139; B. Brzuszek, Massalski Ignacy Jakub herbu własnego (1726-1794), biskup wileński, prezes Komisji Edukacji Narodowej, autor dysertacji kanonistycznych, w: SPT'K, t. 3, H. E. Wyczawski (red.), Warszawa 1982, s. 74-76; Urzędnicy centralni i dygnitarze, dz. cyt., s. 131 (nr 974 i 977), 172 (nr 1356), 216, 220; T. Kasabuła, Ignacy Massalski, dz. cyt., passim (odnośnie do J. K. Kossakowskiego zwł. s. 163-167 i 171-173); P. Nitecki, Biskupi Kościoła, dz. cyt., kol. 217, 285; V. Petkus, Vilniaus vyskupai, dz. cyt., s. 515-555, 841, 858; Wileński stownik biograficzny, s. 170, 222; zob. także: „Korespondent Narodowy i Zagraniczny” 1794, nr 49 (z 21 VI 1794 r.), s. 1103-1109; Materiały Mamerta Herbuta, k. 80r.

${ }^{57}$ Zob. akta ich procesów informacyjnych: ASV, Archivio Concistoriale, Processus Consistoriales, vol. 198, k. 287r-306v (święcenia niższe D. Z. Pilchowski uzyskał w roku 1753 z rąk biskupa A. J. Żółkowskiego, natomiast święceń wyższych udzielił mu w roku 1761 biskup T. I. Zienkowicz - w tym 29 VI tr. prezbiteratu); nadto: [S.] Szantyr, Zbiór wiadomości o Kościele, dz. cyt., t. 1, s. 134; S. K. Kossakowski, Monografie historyczno-genealogiczne, dz. cyt., t. 1, s. 178; J. Kurczewski, Kościót zamkowy czyli katedra wileńska, dz. cyt., t. 1, s. 324 (nr 22), 328 (nr 1); tenże, Biskupstwo wileńskie, dz. cyt., s. 91; Z. Szostkiewicz, Katalog biskupów, dz. cyt., s. 490, 535; HC, t. 6, s. 205, 262; Relationes status dioecesium, dz. cyt., t. 1, s. 15, 17, 559; E. Aleksandrowska, Pilchowski (Pilichowski) Dawid Zygmunt herbu Rogala (1735-1803), jezuita, profesor Szkoły Głównej Wielkiego Księstwa Litewskiego, tłumacz, pisarz, edytor, biskup koadiutor [sic] wileński, w: PSB, t. 26, Wrocław - Warszawa - Kraków - Gdańsk - Łódź 1981, s. 248-251; T. Kasabuła, Ignacy Massalski, dz. cyt., s. 153; P. Nitecki, Biskupi Kościoła, dz. cyt., kol. 216, 355; V. Petkus, Vilniaus vyskupai, dz. cyt., s. 803, 845; Wileński słownik biograficzny, s. 169, 287. 
- skądinąd już o wiele wcześniej - do archidiecezji mohylowskiej), właśnie A. Kossakowski otrzymał nominację na pierwszego sufragana kurlandzkiego przy ordynariuszu Wilna. Tym ostatnim został dotychczasowy pasterz zlikwidowanego biskupstwa inflanckiego - Jan Nepomucen Kossakowski, którego formalna translacja miała miejsce właśnie 8 VIII 1798 r. (na mocy wspomnianego dekretu delegata apostolskiego, którego decyzje papież Pius VI aprobował ex post $17 \mathrm{XI}$ tr.). Uroczysty jego ingres do katedry św. Stanisława odbył się w niedzielę 14 X 1798 r., wcześniej jednak hierarcha ten dopełnił $\mathrm{w}$ stolicy diecezji konsekracji mających odtąd wspomagać go w posłudze pasterskiej sufraganów.

Było ich aż czterech, obok bowiem desygnowanego jeszcze w roku 1793 Dawida Zygmunta Pilchowskiego oraz wspomnianego już Adama Kossakowskiego, którzy obaj czekali na możność przyjęcia sakry od roku 1795, biskupie posługiwanie w Kościele wileńskim podjąć mieli również Jerzy Antoni Połubiński i Adam Kłokocki. Pierwszy, poprzednio archidiakon wileński i przez krótki okres tymczasowy zarządca diecezji w roku 1794 (a ściślej prezydent powołanego po temu - 12 VI tr. - organu kolegialnego), dnia 27 VI $1796 \mathrm{r}$. prekonizowany został tytulariuszem Loryma i sufraganem trockim (a zatem następcą zmarłego jeszcze w roku 1785 Franciszka Gzowskiego ${ }^{58}$. Z kolei Adam Kłokocki, dotychczasowy kanonik kapituły katedralnej smoleńskiej, uzyskał prekonizację na tytulariusza Sidima jeszcze 22 IX 1795 r. jako nominat na sufragana brzeskiego w diecezji łuckiej" ${ }^{59}$ (jej pasterzem był wówczas Adam Naruszewicz,

${ }^{58}$ Akta procesu informacyjnego: ASV, Archivio Concistoriale, Processus Consistoriales, vol. 200, k. 153r-169v (skąd dowiadujemy się m.in., że święcenia kapłańskie otrzymał on 8 VI 1760 r. w katedrze w Wilnie z rąk biskupa T. I. Zienkowicza); nadto: J. Wolff, Senatorowie i dygnitarze, dz. cyt., s. 315-316; [S.] Szantyr, Zbiór wiadomości o Kościele, dz. cyt., t. 1, s. 134; J. Kurczewski, Kościót zamkowy czyli katedra wileńska, dz. cyt., t. 1, s. 327 (nr 3); tenże, Biskupstwo wileńskie, dz. cyt., s. 90; Z. Szostkiewicz, Katalog biskupów, dz. cyt., s. 538; HC, t. 6, s. 265; Relationes status dioecesium, dz. cyt., t. 1, s. 16; L. Zytkowicz, Połubiński Jerzy Antoni z Łubna herbu własnego (1735-1801), ostatni sekretarz wielki litewski, sufragan trocki, w: PSB, t. 27, Wrocław - Warszawa - Kraków - Gdańsk - Łódź 1983, s. 367-368; Urzędnicy centralni i dygnitarze, dz. cyt., s. 181 (nr 1445), 230; P. Nitecki, Biskupi Kościoła, dz. cyt., kol. 355; V. Petkus, Vilniaus vyskupai, dz. cyt., s. 842; Wileński stownik biograficzny, s. 298.

${ }^{59}$ Akta procesu informacyjnego: ASV, Archivio Concistoriale, Processus Consistoriales, vol. 199, k. 402r-413v; nadto: [S.] Szantyr, Zbiór wiadomości o Kościele, dz. cyt., t. 1, s. 134; J. Kurczewski, Kościót zamkowy czyli katedra wileńska, dz. cyt., t. 1, s. 327; tenże, Biskupstwo wileńskie, dz. cyt., s. 90; HC, t. 6, s. 380; Relationes status dioecesium, dz. cyt., t. 1, s. 17; B. Kumor, Ustrój $i$ organizacja, dz. cyt., s. 516; L. Królik, Organizacja diecezji łuckiej i brzeskiej od XVI do XVIII wieku, Lublin 1983, s. 188 (również s. 189, nr 16); P. Nitecki, Biskupi Kościoła, dz. cyt., kol. 206; V. Petkus, Vilniaus vyskupai, dz. cyt., s. 847-848; także: „Dzieje Dobroczynności Krajowej i Zagranicznej” 1823, t. 2, s. 204-205 [nekrolog A. Kłokockiego], skąd dowiadujemy się, że hierarcha ten zmarł w wieku 88 lat dnia 18 IV 1822 r. w Wysokim Litewskim, gdzie od roku 1795 był proboszczem i tam właśnie zwykł był rezydować (w literaturze przedmiotu podawana jest nawet o kilkanaście lat wcześniejsza data śmierci tegoż sufragana); por. Katalog rękopisów Biblioteki Polskiej Akademii Nauk w Krakowie. Sygnatury 4716-4796, s. 33, nr 4751/6. 
zmarły zaledwie w kilka miesięcy później), tym niemniej po wspomnianej reorganizacji granic biskupstw na ziemiach zawładniętych $w$ następstwie II i III rozbioru przez Rosję, również terytorium okręgowej sufraganii brzeskiej przyłączone zostało do diecezji wileńskiej, stąd i ów hierarcha podjąć miał posługę w tymże Kościele partykularnym. Że zaś w ciągu lat 1795/1796-1797 żaden $\mathrm{z}$ owej czwórki nominatów nie zdołał przyjąć święceń biskupich, wszyscy oni pełni kapłaństwa dostąpili właśnie w roku 1798.

$\mathrm{Na}$ wyżej wspomniany rok, jako moment otrzymania sakry przez wyliczonych wcześniej hierarchów, w miarę zgodnie wskazują piszący o nich autorzy, niektórzy zaś dodają przy tym, iż konsekratorem był Jan Nepomucen Kossakowski ${ }^{60}$. Żaden $\mathrm{z}$ owych autorów nie podaje wszakże konkretnej daty dziennej interesującego nas faktu (czy też faktów, nie mamy bowiem pewności, czy wszyscy ci czterej nominaci przyjęli święcenia biskupie w jednym dniu, czy też $w$ różnych terminach). Jan Fijałek nadmienia jedynie w szkicu biograficznym o Dawidzie Zygmuncie Pilchowskim, że jego konsekracja odbyła się jeszcze przed ingresem J. N. Kossakowskiego, który - jak już wspomniano - miał miejsce 14 X $1796 \mathrm{r}^{61}$

$\mathrm{Na}$ wyznaczenie precyzyjniejszego terminu ante quem pozwala wszakże korespondencja wzmiankowanego wcześniej delegata apostolskiego arcybiskupa Lorenzo Litty, który w datowanym na 31 VIII (20 VIII st.st.) 1798 r. i wystosowanym z Sankt Petersburga piśmie do nuncjusza florenckiego Antonio Marii Odeschalchiego (we Florencji rezydował wówczas zmuszony do opuszczenia Rzymu papież Pius VI), stwierdza: „I quattro suffraganei di Vilna, che da più di due anni avevano le bolle da Roma, le quali finora rimaneano senza esecuzione per non aver l'assenso del governo, sono stati finalmente consacrati in Vilna da Monsignor vescovo Kossakowski secondo le forme del Pontificale Romano. Questi vescovi sono: Monsignor David Pilkowski, vescovo di Echini in partibus, suffraganeo di Vilna, Monsignor Adamo Korwin Kossakowski, vescovo di Limira, suffraganeo di Curlandia, Monsignor Giorgio Polubinski, vescovo di Lorima, suffraganeo di Troki, e Monsignor Adamo Klokocki,

${ }^{60}$ M.in.: „Dzieje Dobroczynności Krajowej i Zagranicznej” 1823, t. 2, s. 205; W. Przyałgowski, Żywoty biskupów wileńskich, t. 3, s. 213; J. Kurczewski, Biskupstwo wileńskie, dz. cyt., s. 61, 82, 89-91; J. Fijałek, X. Dawid Pilchowski S.T. i Pr. Kośc. Dr. Profesor Akademii jezuickiej, następnie Szkoły Głównej Wileńskiej. Biskup sufragan wileński (nominat 1793, prekon. i kons. 1798, † 1803). Szkic bio-bibliograficz$n y$, „Kwartalnik Teologiczny Wileński” 1 (1923), z. 1, s. 4; E. Aleksandrowska, Pilchowski (Pilichowski) Dawid Zygmunt, dz. cyt., s. 250; L. Żytkowicz, Potubiński Jerzy Antoni z Łubna, dz. cyt., s. 368; Katalog rękopisów Biblioteki Polskiej Akademii Nauk w Krakowie. Sygnatury 4716-4796, s. 33-34, nr 4751/6-7; Encyklopedia wiedzy o jezuitach, dz. cyt., kol. 284, 508 (gdzie przy D. Z. Pilchowskim błędna data sakry 1 VI 1795 r.).

${ }^{61}$ J. Kurczewski, Kościół zamkowy czyli katedra wileńska, dz. cyt., t. 3, s. 407-408; J. Fijałek, X. Dawid Pilchowski, dz. cyt., s. 4. 
vescovo di Sidina, suffraganeo di Brzesc. Il nuovo vescovo di Vilna, Monsignor Giovanni Kossakowski, m'ha trasmesso in autentica forma i soliti giuramenti prestati da' quattro vescovi suddetti nell'atto della loro consacrazione" 62 . Niestety, wspomnianych tu formularzy z wyznaniem wiary i przysięgą na wierność Stolicy Apostolskiej, opatrzonych zapewne stosowną datą ich złożenia, w tym przypadku tożsamą z dniem konsekracji, brak wśród dokumentów przechowywanych w Archiwum Watykańskim w zbiorze „Iuramenta fidelitatis et Professiones fidei"63.

$\mathrm{Z}$ zacytowanego we fragmencie pisma L. Litty dat owych nie poznajemy, a jedynie możemy wnioskować, że wszystkie cztery interesujące nas tu sakry dopełnione zostały na jakiś czas przed 31 VIII 1798 r., skoro do tego dnia zdążyły już dotrzeć do Sankt Petersburga przesłane przez ordynariusza wileńskiego rzeczone formularze. Czy z kolei za terminus a quo można przyjąć 8 VIII 1798 r., kiedy to przeprowadzona została wspomniana wcześniej reorganizacja, $\mathrm{z}$ czym związane też było powierzenie wówczas stolicy biskupiej $\mathrm{w}$ Wilnie J. N. Kossakowskiemu, wydaje się wątpliwe, nie musiał on bowiem być ordynariuszem loci, by dopełnić tamtego aktu sakry. Zresztą 8 VIII 1798 r. to data formalnego jego potwierdzenia na biskupstwie wileńskim przez uprawnionego do tego przedstawiciela Ojca Świętego, podczas gdy wiążąca decyzja o powierzeniu dotychczasowemu ordynariuszowi inflanckiemu rządów w Kościele wileńskim zapadła o wiele wcześniej na dworze cesarskim w Sankt Petersburgu, o czym też w środowisku kościelnym Wilna wiedziano. Najistotniejszy zaś w całym owym kontekście jest fakt, że J. N. Kossakowski de facto był ordynariuszem w Wilnie i przed wyżej wskazaną datą. Ukazem z 17 IX (6 IX st.st.) 1795 r. cesarzowa Katarzyna II w sposób niekanoniczny, nie oglądając się na Stolicę Świętą, połączyła wakującą diecezję wileńską z biskupstwem inflanckim, powierzając rządy w tym nie posiadającym aprobaty ze strony Rzymu nowym Kościele lokalnym właśnie dotychczasowemu pasterzowi diecezji inflanckiej, a więc Janowi Nepomucenowi Kossakowskiemu. Data 8 VIII 1798 r. nie może zatem być uważana za terminus a quo w omawianej kwestii. Interesującą wskazówkę zawiera natomiast przywołana tu już publikacja J. Fijałka o Dawidzie Zygmuncie

${ }^{62}$ Nonciatures de Russie d'après les documents authentiques, t. 2. Nonciature de Litta 1797-1799, M. J. Rouët de Journel (ed.), Città del Vaticano 1943, s. 253-254 (nr 117).

${ }^{63}$ ASV, Archivio Concistoriale, Iuramenta, vol. 10-11 [dawna sygn. F 2636 i F 2637]. Znajduje się tam wprawdzie iuramentum Dawida Zygmunta Pilchowskiego, wszakże jeszcze z daty 1 II 1794 r., wykonane w Wilnie na ręce biskupa Piotra Samsona Toczyłowskiego (,in residentia soliti” tego hierarchy), w obecności dwóch świadków, mianowicie biskupa nominata koadiutora inflanckiego Jana Nepomucena Kossakowskiego oraz prałata scholastyka kapituły katedralnej smoleńskiej Kazimierza Naruszewicza (ASV, Archivio Concistoriale, Iuramenta, vol. 11, k. 463r-464r). 
Pilchowskim, z której dowiadujemy się, że hierarcha ów 18 VII (7 VII st.st.) 1798 r. poświęcił cmentarz przy kościele św. Stefana w Wilnie, na którym sam $\mathrm{w}$ przyszłości miał spocząć ${ }^{64}$. Nie znając wszakże oryginalnego brzmienia zapiski, na której badacz ten oparł się w tym przypadku (nie wskazał on zresztą na podstawę źródłową), nie możemy rozstrzygnąć, czy Pilchowski dokonał owego aktu już jako nowo konsekrowany biskup, czy też wciąż jeszcze jako sufragan nominat.

Nie ulega zatem wątpliwości, że sakra (sakry?) D. Z. Pilchowskiego, A. Kossakowskiego, J.A. Połubińskiego i A. Kłokockiego odbyła się w Wilnie (choć nie wiemy, czy w katedrze, czy też w innej świątyni) przed 31 VIII 1798 r., zaś głównym konsekratorem był Jan Nepomucen Kossakowski. W tym miejscu wspomnieć należy, iż hierarcha ów „w latach 1794-1803 prowadził obszerny i szczegółowy dziennik, bardzo cenne źródło", z którego zapewne dowiedzielibyśmy się więcej w interesującej nas tu kwestii, jednak został on "spalony w roku 1944 z Biblioteką Krasińskich (rkp 5711)" (L. Żytkowicz) ${ }^{65}$. W kilka tygodni po czterech sufraganach dla diecezji wileńskiej konsekrowani zostali (tyle, że w Połocku) dwaj inni biskupi katoliccy, którzy mieli pełnić posługę pasterską w granicach Cesarstwa Rosyjskiego, mianowicie pierwszy ordynariusz miński Jakub Ignacy Dederko (skądinąd kanonik wileński) i sufragan połocki w archidiecezji mohylowskiej Cyprian Odyniec, o czym również doniósł nuncjuszowi Odeschalchiemu $\mathrm{w}$ swej korespondencji dyplomatycznej delegat apostolski Litta (w liście z 2 X (21 IX st.st.) 1798 r. $)^{66}$.

Nie było dotychczas jeszcze mowy o konsekracji Jana Nepomucena Kossakowskiego, który z jednej strony zamyka poczet XVIII-wiecznych pasterzy Kościoła wileńskiego, z drugiej zaś był - jak wyżej wskazano - konsekratorem

${ }^{64}$ J. Fijałek, X. Dawid Pilchowski, dz. cyt., s. 4.

${ }^{65}$ L. Żytkowicz, Kossakowski Jan Nepomucen herbu Ślepowron, przydomek Korwin (1755-1808), biskup inflancki i wileński, w: Polski słownik biograficzny, t. 14, Wrocław - Warszawa - Kraków - Gdańsk - Łódź 1968-1969, s. 266-267. Biskup ten był również autorem obejmującego lata 1755-1781 pamiętnika, wydanego drukiem przez Józefa Weyssenhoffa (Pamiętnik ks. Jana Nepomucena Kossakowskiego, biskupa wileńskiego, (ur. 1755 † 1808), wyd. J. Weyssenhoff, „Biblioteka Warszawska” 55 (1895), t. 2, s. 195-237 i 454-475). Tamtej edycji towarzyszyła niezrealizowana zapowiedź publikacji również pozostałych części „korpusu” autobiograficznego J. N. Kossakowskiego, na który składały się nadto trzy różne dzienniki, z których pierwszy traktował o okresie od 1 IX 1781 do 16 IX 1782 r., drugi - odpowiednio - od 1 VII do 1 X 1793 r., trzeci zaś był właśnie za ów okres od 1 I 1794 do 31 VII 1803 r. (tamże, s. 195-196). Jakkolwiek AndrzejCieński utrzymuje, że „losy rękopisu, którym dysponował wydawca, nie są [obecnie] znane" (A. Cieński, Pamiętnikarstwo polskie XVIII wieku, Wrocław - Warszawa - Kraków - Gdańsk - Łódź 1981, s. 133-134), w rzeczywistości jednak całość spłonęła w roku 1944. Co najwyżej żywić można nadzieję, że niedoszły wydawca zdążył sporządzić na swój użytek odpis owych rękopisów i że tego rodzaju kopia gdzieś ocalała.

${ }^{66}$ Nonciatures de Russie, dz. cyt., t. 2, s. 265-266 (nr 123). 
kilku innych biskupów, do posługi w tej właśnie diecezji ustanowionych. W gronie episkopatu znalazł się on na niedługo przed upadkiem Rzeczypospolitej Obojga Narodów, prekonizowany 23 IX 1793 r. przez papieża Piusa VI tytulariuszem Loryma i koadiutorem biskupa inflanckiego Józefa Kazimierza Kossakowskiego, który w tym czasie sam był już koadiutorem z kolei przy ordynariuszu wileńskim Ignacym Jakubie Massalskim ${ }^{67}$. Zdaje się tedy nie ulegać wątpliwości, iż właśnie z rąk albo J. K. Kossakowskiego, albo też I. J. Massalskiego przyjął on święcenia biskupie, który to uroczysty akt miał miejsce w niedzielę 2 II 1794 r. (tj. w święto Ofiarowania Pańskiego) w katedrze św. Stanisława w Wilnie ${ }^{68}$. W dostępnych nam świadectwach, tudzież literaturze przedmiotu, brak niestety potrzebnych dla kompletności opisu imion trzech hierarchów, przez posługę których duchowny ten dostąpił pełni kapłaństwa ${ }^{69}$ (jednym ze współkonsekratorów mógł być biskup Piotr Samson Toczyłowski, którego obecność w stolicy Wielkiego Księstwa Litewskiego w dniu poprzedzającym ową sakrę jest poświadczona poprzez fakt, że właśnie na jego ręce wykonał tamże 1 II tr. przysięgę na wierność Stolicy Apostolskiej desygnowany na sufraganię wileńską Dawid Zygmunt Pilchowski - zresztą w obecności J. N. Kossakowskiego, po raz ostatni określonego wówczas mianem nominata ${ }^{70}$. Kwestia ta jest tymczasem bardzo istotna dla dalszej analizy, a konkretnie pod kątem przyporządkowania

${ }^{67}$ Zob. akta procesu informacyjnego: ASV, Archivio Concistoriale, Processus Consistoriales, vol. 196, k. 110r-131v (gdzie m.in. dokumenty odnoszące się do poszczególnych stopni święceń, przy czym tonsurę i święcenia niższe J. N. Kossakowski otrzymał 20 XII 1777 r. w kolegiacie św. Jana Chrzciciela $\mathrm{w}$ Warszawie $\mathrm{z}$ rąk koadiutora ordynariusza kijowskiego Kaspra Kazimierza Cicieszowskiego, natomiast na prezbitera wyświęcił go 26 III 1787 r. w warszawskim kościele pw. Krzyża Św. biskup Józef Kazimierz Kossakowski - tamże, k. 124r-v); nadto: [S.] Szantyr, Zbiór wiadomości o Kościele, dz. cyt., t. 1, s. 134; W. Przyałgowski, Żywoty biskupów, dz. cyt., t. 3, s. 205-238; S. K. Kossakowski, Monografie historyczno-genealogiczne, dz. cyt., t. 1, s. 176-177; M. Loret, Kościót katolicki w poczq̨tkach panowania Aleksandra I (1801-1815), „Biblioteka Warszawska” 73 (1913), t. 1, s. 503-504; J. Kurczewski, Kościót zamkowy czyli katedra wileńska, dz. cyt., t. 1, s. 317-318 (nr 29); tenże, Biskupstwo wileńskie, dz. cyt., s. 61-63; Z. Szostkiewicz, Katalog biskupów, dz. cyt., s. 490; Relationes status dioecesium, dz. cyt., t. 1, s. 12, 559; F. Stopniak, Kossakowski Jan Nepomucen (przydomek Korwin) herbu Ślepowron (1755-1808), biskup inflancki, potem wileński, autor pamiętników, w: SPTK, t. 2, H. E. Wyczawski (red.), Warszawa 1982, s. 363-365 (gdzie błędnie przypisane zostały J. N. Kossakowskiemu także pamiętniki J. K. Kossakowskiego); T. Krahel, Zarys dziejów (archi)diecezji, dz. cyt., s. 28 (nr 30); P. Nitecki, Biskupi Kościoła, dz. cyt., kol. 217; V. Petkus, Vilniaus vyskupai, dz. cyt., s. 559--571; Wileński słownik biograficzny, s. 169.

${ }^{68}$ M.in.: W. Przyałgowski, Żywoty biskupów wileńskich, t. 3, s. 209; L. Żytkowicz, Kossakowski Jan Nepomucen, dz. cyt., s. 266; V. Petkus, Vilniaus vyskupai, dz. cyt., s. 561.

${ }^{69}$ Tak np. brak jakiejkolwiek w ogóle wzmianki o tej sakrze w kontynuacji przywoływanej tu już kilkakrotnie kroniki bernardynów wileńskich, w której o J. N. Kossakowskim, jako o konsekrowanym biskupie, czytamy dopiero pod datą 20 II 1794 r. (po raz kolejny 3 III tr.) - Liber secundus historiae domus Patrum Bernardinorum, s. 375.

${ }^{70}$ ASV, Archivio Concistoriale, Iuramenta, vol. 463r-464r (Vilnensis suffraganeus 1794); por. Materiały Mamerta Herbuta, k. 73r-80r; zob. także: wyżej przyp. 63. 
wyliczonych dotychczas hierarchów do wyróżnianych w literaturze przedmiotu linii sukcesji apostolskiej.

Nie mniej istotna jest w tej samej perspektywie kwestia święceń biskupich wspomnianego na samym początku Mikołaja Jana Zienkowicza, ordynariusza wileńskiego $\mathrm{z}$ lat 1730-1762, której omówienie świadomie odłożyliśmy na zakończenie tej części analizy. Jak była już o tym wzmianka, duchowny ów znalazł się $\mathrm{w}$ gronie episkopatu jeszcze $\mathrm{w}$ roku 1718 , kiedy to jako nominat (od 19 III 1717 r.) na sufraganię żmudzką uzyskał 27 IV tr. prekonizację na biskupa tytularnego Juliopolis. Piszący o M. J. Zienkowiczu autorzy nie podają jakichkolwiek informacji na temat jego sakry, nie natrafiwszy zapewne na jakiekolwiek świadectwa w owej materii ${ }^{71}$. Również nam nie udało się zgromadzić pełnych danych na temat aktu święceń biskupich rzeczonego hierarchy, tym niemniej możliwe okazało się poczynienie istotnych $\mathrm{w}$ tejże kwestii ustaleń. I tak w niejednokrotnie już tu przywoływanej kronice wileńskiego klasztoru bernardynów, w zwartej tamże pod datą 23 I 1762 r. zapisce, informującej o śmierci sędziwego biskupa Zienkowicza, przytoczono - w zupełności zgoła nieoczekiwanie - kilka najważniejszych informacji z curriculum vitae zmarłego hierarchy, a wśród nich i tę, że „,consecratus [est] in suffraganeum Samogitiensem [anno] 1718, die 6. Xbris"72.

Data 6 XII 1718 r. (był to wtorek, wszakże wspomnienie liturgiczne św. Mikołaja Biskupa) znajduje jednoznaczne potwierdzenie we współczesnym owemu wydarzeniu źródle, też zresztą stanowiącym kronikę domu zakonnego, mianowicie wileńskiego kolegium Towarzystwa Jezusowego. W odniesieniu do tego właśnie dnia zanotowano tam, że w Wilnie, „in templo Arcensi" (tj. w katedrze św. Stanisława, nazywanej też nieraz kościołem zamkowym), odbyła się konsekracja Mikołaja Jana Zienkowicza „in episcopum Iuliopolitanum", w której to uroczystości wzięła udział delegacja wileńskich jezuitów ${ }^{73}$. Niestety, także $\mathrm{w}$ tej kronice nie wymieniono osoby głównego konsekratora oraz współkonsekratorów.

Pod datą 3 XII tr. wyczytujemy wszakże w cytowanym źródle, że z racji przypadającego wówczas wspomnienia liturgicznego św. Franciszka Ksawerego „Illustrissimus episcopus Vilnensis, item Illustrissimus episcopus Samogitiae et Illustrissimus suffraganeus Vilnensis sacra habuerunt ad altare S. Francisci

${ }^{71}$ M.in.: W. Przyałgowski, Żywoty biskupów wileńskich, t. 3, s. 134; Encyklopedia powszechna [Orgelbranda], t. 28, s. 610 (F. M. Sobieszczański); J. Kurczewski, Biskupstwo wileńskie, dz. cyt., s. 53; M. Wolłonczewski, Biskupstwo żmujdzkie, s. 94; V. Petkus, Vilniaus vyskupai, dz. cyt., s. 503.

${ }^{72}$ Hystoria Conventus Custodialis Vilnensis, s. 30.

${ }^{73}$ Diarium Collegii Societatis Jesu, dz. cyt., s. 386/387 („1718 December 6”). 
Xaverii" (mowa o liturgii sprawowanej w należącym do duchowych synów św. Ignacego Loyoli miejscowym kościele akademickim św. Jana Chrzciciela i św. Jana Ewangelisty $)^{74}$. Na trzy dni przed sakrą tytulariusza juliopolitańskiego widzimy zatem przebywających $\mathrm{w}$ Wilnie trzech potrzebnych dla dopełnienia aktu święceń biskupich członków katolickiego episkopatu, mianowicie ordynariuszy: wileńskiego Konstantego Kazimierza Brzostowskiego i żmudzkiego Aleksandra Horaina (nie należy go mylić $\mathrm{z}$ jego młodszym imiennikiem i zarazem krewniakiem, który w roku 1731 został sufraganem na Żmudzi po M. J. Zienkowiczu) oraz miejscowego sufragana Macieja Józefa Ancutę, wówczas już będącego zarazem koadiutorem przy K. K. Brzostowskim (nie wykluczone, że na miejscu obecny był również ówczesny sufragan białoruski Karol Piotr Pancerzyński). W nich zatem należy upatrywać trójki konsekratorów interesującego nas hierarchy, który przed swym wyniesieniem do godności biskupiej związany był jak najściślej z wileńskim środowiskiem kościelnym, jako tamtejszy kanonik, zaś więzy te bynajmniej nie uległy rozluźnieniu po nominacji na żmudzką sufraganię. Jako biskup wcale nie przeniósł się on na Żmudź, by tam rezydować, lecz nadal przebywał najczęściej w Wilnie, a do diecezji, w której miał sprawować posługi pontyfikalne, udawał się tylko okresowo ${ }^{75}$. Dlatego też właśnie w stolicy Wielkiego Księstwa Litewskiego odbyła się rzeczona sakra, której - jak mamy prawo uważać niemal za pewne - udzielił najprawdopodobniej ordynariusz loci Konstanty Kazimierz Brzostowski lub też ewentualnie pasterz diecezji żmudzkiej Aleksander Horain. Od razu w tym kontekście trzeba nadmienić, że ów drugi hierarcha, pierwotnie zresztą piastujący godność sufragana wileńskiego, święcenia biskupie otrzymał w roku 1705 właśnie z rąk K. K. Brzostowskiego ${ }^{76}$. Obojętnie zatem, czy konsekratorem Mikołaja Jana Zienkowicza był ordynariusz wileński, czy też żmudzki, w obu przypadkach mamy do czynienia z tą samą linią sukcesji apostolskiej.

${ }^{74}$ Tamże, s. 386/387 („1718 December 3. Festum S. Francisci Xaverii”).

${ }^{75} \mathrm{Nie}$ należy przy tym zapominać, że w latach 1724-1729 M. J. Zienkowicz piastował zarazem funkcję pisarza wielkiego litewskiego; zob. W. Przyałgowski, Żywoty biskupów, dz. cyt., t. 3, s. 134; M. Wołłonczewski, Biskupstwo żmujdzkie, s. 94; J. Wolff, Senatorowie i dygnitarze, dz. cyt., s. 278; Urzędnicy centralni i dygnitarze, dz. cyt., s. 131 (nr 970), 253.

${ }^{76}$ J. Kurczewski, Kościół zamkowy czyli katedra wileńska, dz. cyt., t. 3, s. 280; J. Poplatek, Wykaz alumnów, dz. cyt., s. 257 (nr 293). 
Sakry Pasterzy Kościoła wileńskiego z 2. i 3. tercji XVIII w.

\begin{tabular}{|c|c|c|c|c|c|}
\hline $\begin{array}{c}\text { Imię } \\
\text { i nazwisko }\end{array}$ & Lata posługi & Data sakry & $\begin{array}{l}\text { Miejsce } \\
\text { sakry }\end{array}$ & $\begin{array}{l}\text { Główny } \\
\text { konsekrator }\end{array}$ & Współkonsekratorzy \\
\hline 1 & 2 & 3 & 4 & 5 & 6 \\
\hline \multicolumn{6}{|c|}{ ORDYNARIUSZE } \\
\hline $\begin{array}{l}\text { Mikołaj Jan } \\
\text { Zienkowicz }\end{array}$ & $1730-1762$ & $6 \mathrm{XII} 1718 \mathrm{r}$. & $\begin{array}{l}\text { Wilno, katedra } \\
\text { św. Stanisława }\end{array}$ & $\begin{array}{l}\text { [? Konstanty Kazimierz } \\
\text { Brzostowski, biskup } \\
\text { ordynariusz wileński, } \\
\text { lub Aleksander } \\
\text { Horain, biskup } \\
\text { ordynariusz żmudzki] }\end{array}$ & $\begin{array}{l}{[? \text { Aleksander Horain, }} \\
\text { biskup ordynariusz } \\
\text { żmudzki lub Konstanty } \\
\text { Kazimierz Brzostowski, } \\
\text { biskup ordynariusz } \\
\text { wileński; } \\
\text { ? Maciej Józef Ancuta, } \\
\text { biskup tytularny } \\
\text { Mosynopolis, koadiutor } \\
\text { i sufragan wileński] }\end{array}$ \\
\hline $\begin{array}{l}\text { Ignacy Jakub } \\
\text { Massalski }\end{array}$ & $1762-1794$ & $2 \mathrm{~V} 1762 \mathrm{r}$. & $\begin{array}{l}\text { Wilno, katedra } \\
\text { św. Stanisława }\end{array}$ & $\begin{array}{l}\text { Aleksander Horain, } \\
\text { biskup tytularny } \\
\text { Hirina i sufragan } \\
\text { żmudzki }\end{array}$ & $\begin{array}{l}\text { Antoni Józef Żółkowski, } \\
\text { biskup tytularny Alalia } \\
\text { i sufragan wileński; } \\
\text { Tomasz Ignacy } \\
\text { Zienkowicz, biskup } \\
\text { tytularny Areopolis } \\
\text { i sufragan białoruski }\end{array}$ \\
\hline \begin{tabular}{|l|} 
Jan \\
Nepomucen \\
Kossakowski
\end{tabular} & $1798-1808$ & 2 II 1794 r. & $\begin{array}{l}\text { Wilno, katedra } \\
\text { św. Stanisława }\end{array}$ & $\begin{array}{l}\text { [? Ignacy Jakub } \\
\text { Massalski, biskup } \\
\text { ordynariusz wileński } \\
\text { lub Józef Kazimierz } \\
\text { Kossakowski, biskup } \\
\text { ordynariusz inflancki } \\
\text { i koadiutor wileński] }\end{array}$ & $\begin{array}{l}\text { [? Piotr Samson } \\
\text { Toczyłowski, biskup } \\
\text { tytularny Belle, były } \\
\text { sufragan wileński] }\end{array}$ \\
\hline \multicolumn{6}{|c|}{ KOADIUTORZY } \\
\hline $\begin{array}{l}\text { Józef Julian } \\
\text { Sapieha }\end{array}$ & $1737-1754$ & $1 \mathrm{IX} 1737 \mathrm{r}$. & $\begin{array}{l}\text { Wilno, katedra } \\
\text { św.Stanisława }\end{array}$ & $\begin{array}{l}\text { Mikołaj Jan } \\
\text { Zienkowicz, biskup } \\
\text { ordynariusz wileński }\end{array}$ & $\begin{array}{l}\text { Jozafat Karp, biskup } \\
\text { ordynariusz żmudzki; } \\
\text { Aleksander Horain, } \\
\text { biskup tytularny Hirina } \\
\text { i sufragan żmudzki }\end{array}$ \\
\hline \begin{tabular}{|l|} 
Józef \\
Kazimierz \\
Kossakowski
\end{tabular} & $1791-1794$ & $30 \mathrm{IV} 1775 \mathrm{r}$. & $\begin{array}{l}\text { Warszawa, } \\
\text { kościół } \\
\text { Krzyża Sw. } \\
\text { (misjonarzy- } \\
\text {-lazarystów) }\end{array}$ & $\begin{array}{l}\text { Ignacy Jakub } \\
\text { Massalski, biskup } \\
\text { ordynariusz wileński }\end{array}$ & $\begin{array}{l}\text { Antoni Onufry Okęcki, } \\
\text { biskup ordynariusz } \\
\text { chełmski, nominat } \\
\text { koadiutor poznański; } \\
\text { Józef Ignacy Rybiński, } \\
\text { biskup tytularny Europa } \\
\text { i koadiutor włocławski }\end{array}$ \\
\hline
\end{tabular}


SUFRAGANI

\begin{tabular}{|c|c|c|c|c|c|}
\hline 1 & 2 & 3 & 4 & 5 & 6 \\
\hline $\begin{array}{l}\text { Józef Julian } \\
\text { Sapieha }\end{array}$ & $\begin{array}{c}\text { 1737-1754 } \\
\text { (wileński) }\end{array}$ & \multicolumn{4}{|c|}{ zob. wyżej: Koadiutorzy } \\
\hline $\begin{array}{l}\text { Antoni Józef } \\
\text { Żółkowski }\end{array}$ & $\begin{array}{c}1744-1755 \\
\text { (białoruski) } \\
1755-1763 \\
\text { (wileński) }\end{array}$ & 21 II 1745 r. & $\begin{array}{l}\text { Wilno, } \\
\text { [katedra św. } \\
\text { Stanisława] }\end{array}$ & $\begin{array}{l}\text { Mikołaj Jan } \\
\text { Zienkowicz, biskup } \\
\text { ordynariusz wileński }\end{array}$ & $\begin{array}{l}\text { Józef Dominik Puzyna, } \\
\text { biskup ordynariusz } \\
\text { inflancki; } \\
\text { Antoni Dominik } \\
\text { Tyszkiewicz, biskup } \\
\text { ordynariusz żmudzki }\end{array}$ \\
\hline $\begin{array}{l}\text { Tomasz } \\
\text { Ignacy } \\
\text { Zienkowicz }\end{array}$ & $\begin{array}{c}1755-1763 \\
\text { (białoruski) } \\
1763-1781 \\
\text { (wileński) }\end{array}$ & $9 \times 11755 r$. & $\begin{array}{l}\text { Wilno, } \\
\text { katedra } \\
\text { św. Stanisława }\end{array}$ & $\begin{array}{l}\text { Antoni Dominik } \\
\text { Tyszkiewicz, biskup } \\
\text { ordynariusz żmudzki }\end{array}$ & $\begin{array}{l}\text { Aleksander Horain, } \\
\text { biskup tytularny Hirina } \\
\text { i sufragan żmudzki; } \\
\text { Antoni Józef Żółkowski, } \\
\text { biskup tytularny Alalia } \\
\text { i sufragan wileński }\end{array}$ \\
\hline $\begin{array}{l}\text { Jan Stefan } \\
\text { Giedroyć }\end{array}$ & $\begin{array}{r}1763-1765 \\
\text { (białoruski) }\end{array}$ & 12 II $1764 r$. & $\begin{array}{l}\text { Wilno, } \\
\text { katedra } \\
\text { św. Stanisława }\end{array}$ & $\begin{array}{l}\text { Ignacy Jakub } \\
\text { Massalski, biskup } \\
\text { ordynariusz wileński }\end{array}$ & $?$ \\
\hline $\begin{array}{l}\text { Tadeusz } \\
\text { Benedykt } \\
\text { (Feliks) } \\
\text { Towiański }\end{array}$ & $\begin{array}{r}1766-1772 \\
\text { (białoruski) }\end{array}$ & $411767 \mathrm{r}$. & $\begin{array}{l}\text { Warszawa, } \\
\text { kościół } \\
\text { Stygmatów } \\
\text { św. Franciszka } \\
\text { Serafickiego } \\
\text { (franciszka- } \\
\text { nów konwen- } \\
\text { tualnych) }\end{array}$ & $?$ & $?$ \\
\hline $\begin{array}{l}\text { Stanisław } \\
\text { Siestrzeńce- } \\
\text { wicz }\end{array}$ & $\begin{array}{r}1773-1782 \\
\text { (białoruski) }\end{array}$ & $\begin{array}{c}3 \times(1 \mathrm{IX}) \\
1773 \mathrm{r} .\end{array}$ & $\begin{array}{l}\text { Wilno } \\
\text { [?] }\end{array}$ & $\begin{array}{l}\text { Jerzy Mikołaj Hylzen, } \\
\text { biskup - były } \\
\text { ordynariusz smoleński }\end{array}$ & $?$ \\
\hline \begin{tabular}{|l|} 
Piotr \\
Samson \\
Toczyłowski
\end{tabular} & $\begin{array}{c}\text { 1782-1793 } \\
\text { (wileński) } \\
\text { [1808] }\end{array}$ & 29 XII 1782 r. & $\begin{array}{l}\text { Wilno, kościół } \\
\text { akademicki } \\
\text { św. Jana } \\
\text { Chrzciciela } \\
\text { i św. Jana } \\
\text { Ewangelisty }\end{array}$ & $\begin{array}{l}\text { Ignacy Jakub } \\
\text { Massalski, biskup } \\
\text { ordynariusz wileński }\end{array}$ & $\begin{array}{l}\text { Tomasz Ignacy } \\
\text { Zienkowicz, biskup } \\
\text { tytularny Areopolis, } \\
\text { były sufragan wileński; } \\
\text { Walenty Wołczacki, } \\
\text { biskup tytularny } \\
\text { Tamasus }\end{array}$ \\
\hline
\end{tabular}




\begin{tabular}{|c|c|c|c|c|c|}
\hline 1 & 2 & 3 & 4 & 5 & 6 \\
\hline $\begin{array}{l}\text { Franciszek } \\
\text { Gzowski }\end{array}$ & $\begin{array}{c}1782-1785 \\
\text { (trocki) }\end{array}$ & 29 XII 1782 r. & $\begin{array}{l}\text { Wilno, kościół } \\
\text { akademicki } \\
\text { św. Jana } \\
\text { Chrzciciela } \\
\text { iśw. Jana } \\
\text { Ewangelisty }\end{array}$ & $\begin{array}{l}\text { Ignacy Jakub } \\
\text { Massalski, biskup } \\
\text { ordynariusz wileński }\end{array}$ & $\begin{array}{l}\text { Tomasz Ignacy } \\
\text { Zienkowicz, biskup } \\
\text { tytularny Areopolis, } \\
\text { były sufragan wileński; } \\
\text { Walenty Wołczacki, } \\
\text { biskup tytularny } \\
\text { Tamasus }\end{array}$ \\
\hline $\begin{array}{l}\text { Dawid } \\
\text { Zygmunt } \\
\text { Pilchowski }\end{array}$ & $\begin{array}{c}\text { 1795-1803 } \\
\text { (wileński) }\end{array}$ & $\begin{array}{l}1798 \mathrm{r} . \\
\text { [przed } \\
31 \mathrm{VIII}]\end{array}$ & $\begin{array}{l}\text { Wilno } \\
{[?]}\end{array}$ & $\begin{array}{l}\text { Jan Nepomucen } \\
\text { Kossakowski, biskup } \\
\text { ordynariusz wileński } \\
\text { (? inflancki) }\end{array}$ & $?$ \\
\hline $\begin{array}{l}\text { Adam } \\
\text { Kossakowski }\end{array}$ & $\begin{array}{c}1795-1828 \\
\text { (kurlandzki) }\end{array}$ & $\begin{array}{l}1798 \mathrm{r} . \\
\text { [przed } \\
31 \mathrm{VIII}]\end{array}$ & $\begin{array}{l}\text { Wilno } \\
{[?]}\end{array}$ & $\begin{array}{l}\text { Jan Nepomucen } \\
\text { Kossakowski, biskup } \\
\text { ordynariusz wileński } \\
\text { (? inflancki) }\end{array}$ & $?$ \\
\hline $\begin{array}{l}\text { Adam } \\
\text { Kłokocki }\end{array}$ & $\begin{array}{c}\text { 1798-1822 } \\
\text { (brzeski) }\end{array}$ & $\begin{array}{c}1798 \mathrm{r} . \\
\text { [przed } 31 \\
\text { VIII] }\end{array}$ & $\begin{array}{l}\text { Wilno } \\
{[?]}\end{array}$ & $\begin{array}{l}\text { Jan Nepomucen } \\
\text { Kossakowski, biskup } \\
\text { ordynariusz wileński } \\
\text { (? inflancki) }\end{array}$ & $?$ \\
\hline $\begin{array}{l}\text { Jerzy Antoni } \\
\text { Połubiński }\end{array}$ & $\begin{array}{c}\text { 1796-1801 } \\
\text { (trocki) }\end{array}$ & $\begin{array}{c}1798 \mathrm{r} . \\
\text { [przed } 31 \\
\text { VIII] }\end{array}$ & $\begin{array}{l}\text { Wilno } \\
{[?]}\end{array}$ & $\begin{array}{l}\text { Jan Nepomucen } \\
\text { Kossakowski, biskup } \\
\text { ordynariusz wileński } \\
\text { (? inflancki) }\end{array}$ & $?$ \\
\hline \multicolumn{6}{|c|}{ INNI BISKUPI TYTULARNI } \\
\hline $\begin{array}{l}\text { Walenty } \\
\text { Wołczacki } \\
\text { (Wołłczacki) }\end{array}$ & $1774-1810$ & 21 VIII $1774 \mathrm{r}$. & $\begin{array}{l}\text { Warszawa, } \\
\text { kościół } \\
\text { św. Jacka } \\
\text { (dominika- } \\
\text { nów) }\end{array}$ & $\begin{array}{l}\text { Giuseppe Garampi, } \\
\text { arcybiskup tytularny } \\
\text { Berytus, nuncjusz } \\
\text { apostolski w } \\
\text { Rzeczypospolitej } \\
\text { Obojga Narodów }\end{array}$ & $\begin{array}{l}\text { Antoni Onufry Okęcki, } \\
\text { biskup ordynariusz } \\
\text { chełmski; } \\
\text { Gabriel Wodzyński } \\
\text { (Wodziński), biskup } \\
\text { ordynariusz smoleński }\end{array}$ \\
\hline $\begin{array}{l}\text { Mikołaj } \\
\text { Bykowski }\end{array}$ & $\begin{array}{c}1786-\text { po } \\
1803\end{array}$ & 5 XI $1786 r$. & $\begin{array}{l}\text { Warszawa, } \\
\text { kościół św. } \\
\text { Kazimierza } \\
\text { (sakramentek) }\end{array}$ & $\begin{array}{l}\text { Józef Kazimierz } \\
\text { Kossakowski, biskup } \\
\text { ordynariusz inflancki }\end{array}$ & $\begin{array}{l}\text { Adam Naruszewicz, } \\
\text { biskup tytularny } \\
\text { Emaus i koadiutor } \\
\text { smoleński; } \\
\text { Antonin Andrzej } \\
\text { Malinowski, biskup } \\
\text { tytularny Cinna } \\
\text { i sufragan żmudzki }\end{array}$ \\
\hline \begin{tabular}{|l|} 
Józef \\
Prószyński \\
(Pruszyński)
\end{tabular} & $1777-1790$ & $17 \| 1777 r$. & $\begin{array}{l}\text { Warszawa, } \\
\text { kościół } \\
\text { Krzyża Św. } \\
\text { (misjonarzy- } \\
\text {-lazarystów) }\end{array}$ & $\begin{array}{l}\text { Giovanni Andrea } \\
\text { Archetti, arcybiskup } \\
\text { tytularny Chalcedonu, } \\
\text { nuncjusz apostolski } \\
\text { w Rzeczypospolitej } \\
\text { Obojga Narodów }\end{array}$ & $\begin{array}{l}\text { Jan Stefan Giedroyć, } \\
\text { biskup ordynariusz } \\
\text { inflancki (wendeński); } \\
\text { Gabriel Wodzyński } \\
\text { (Wodziński), biskup } \\
\text { ordynariusz smoleński }\end{array}$ \\
\hline
\end{tabular}


Mając już zebrane owe podstawowe informacje na temat sakr osiemnastu (czy też - jeśli uwzględnić również Józefa Prószyńskiego - dziewiętnastu) członków katolickiego episkopatu Rzeczypospolitej Obojga Narodów z drugiej oraz trzeciej tercji XVIII stulecia, związanych przez swą posługę z diecezją wileńską, możemy dokonać ich przyporządkowania do wyróżnianych w literaturze przedmiotu linii sukcesji święceń biskupich. O dwóch spośród tych linii, mianowicie rzymskiej (Rebiby) i polskiej (Uchańskiego), była nieco obszerniej mowa $\mathrm{w}$ artykule z poprzedniego tomu „Rocznika Teologii Katolickiej”, nie ma więc potrzeby dokonywać raz jeszcze bliższego ich opisu, tudzież wyjaśniać, skąd biorą one swoje miano oraz jak daleko wstecz udało się badaczom dokonać ich rekonstrukcji. Tak się tymczasem złożyło, że właśnie do tych dwóch linii należą niemal wszyscy (albo i wszyscy, jako że nie jesteśmy aktualnie w stanie tego rozstrzygnąć w zasadzie tylko w odniesieniu do T. B. F. Towiańskiego) hierarchowie, o których była wyżej mowa (przy zastrzeżeniu wszakże, iż w przypadku M. J. Zienkowicza i J. N. Kossakowskiego dokonana przez nas hipotetycznie identyfikacja osoby głównego konsekratora wymaga potwierdzenia). A zatem ową mogącą poszczycić się licznym zastępem papieży, do niej przynależących, linię rzymską reprezentują pośród XVIII-wiecznych pasterzy Kościoła wileńskiego (wyliczając wedle starszeństwa sakry): Ignacy Jakub Massalski, Jan Stefan Giedroyć, Walenty Wołczacki (Wołłczacki), Józef Kazimierz Kossakowski, Józef Prószyński, Franciszek Gzowski, Piotr Samson Toczyłkowski, Mikołaj Bykowski oraz - póki co z pewnym znakiem zapytania - Jan Nepomucen Kossakowski i konsekrowani przez niego: Adam Kłokocki, Adam Kossakowski, Dawid Zygmunt Pilchowski i Jerzy Antoni Połubiński. Wspólny ich wywód sukcesji, doprowadzony wszakże tylko do pierwszego ogniwa, w którym łączą się uwzględnione tu odnogi tej linii, ukazano na widniejącym poniżej schemacie nr 1 (data w nawiasie odnosi się do roku otrzymania sakry), przy czym w przypadku J. N. Kossakowskiego przyjęto z dwóch przedstawionych wcześniej możliwości ów dłuższy „wariant”, tj. przyjęcie święceń biskupich z rąk J. K. Kossakowskiego, a nie I. J. Massalskiego.

Jak na podstawie schematu nr 1 nietrudno dostrzec, prócz dwóch biskupów nie będących ani ordynariuszami, ani też sufraganami, tj. W. Wołczackiego i J. Prószyńskiego, konsekrowanych zaś przez kolejnych nuncjuszy apostolskich w Rzeczypospolitej Obojga Narodów, wszyscy pozostali przynależność do owej linii zawdzięczali bezpośrednio lub też pośrednio Ignacemu Jakubowi Massalskiemu, który święcenia biskupie otrzymał z rąk Aleksandra Horaina, ten 
zaś konsekrowany został również przez jednego z nuncjuszów (nie wykluczone, że także konsekratorem sufragana Towiańskiego był nuncjusz, a więc w owym przypadku Antonio Eugenio Visconti). Tytułem natomiast uzupełnienia do artykułu z poprzedniego tomu „Rocznika Teologii Katolickiej” dodatkowo uwzględniono $\mathrm{w}$ wywodzie dwóch XIX-wiecznych sufraganów $\mathrm{z}$ diecezji wileńskiej, mianowicie Nikodema Puzynę i Tadeusza Kundzicza, w przypadku których stwierdziliśmy wówczas, że wobec niedysponowania w tamtym momencie informacją, kto udzielił święceń biskupich ich konsekratorowi, tj. Adamowi Kossakowskiemu, nie jesteśmy w stanie dokonać ich przyporządkowania do tej lub innej linii sukcesji ${ }^{77}$. Obecnie już możemy to uczynić, co też zostało tu uwidocznione.

Pozostali hierarchowie, uwzględnieni $\mathrm{w}$ obecnej analizie, reprezentują linię polską, która jakkolwiek wyprowadzana jest od zmarłego w roku 1581 prymasa Jakuba Uchańskiego, tym niemniej w sposób pewny da się dowieść jedynie do piątego $\mathrm{z}$ kolei jego następcy na stolicy prymasowskiej, arcybiskupa Wawrzyńca Gembickiego (zmarłego w 1624 r.). Chodzi zatem o grono pięciu hierarchów, którymi są (i tym razem wyliczając wedle starszeństwa sakry): Mikołaj Jan Zienkowicz, Józef Julian Stanisław Sapieha, Antoni Józef Żółkowski, Tomasz Ignacy Zienkowicz i Stanisław Siestrzeńcewicz. O ile w przypadku tego ostatniego hierarchy przynależność do rzeczonej linii jest bezdyskusyjna, o tyle w odniesieniu do M. J. Zienkowicza (w konsekwencji i trzech pozostałych spośród wymienionych biskupów, których wywód do niego właśnie prowadzi) nie sposób nie zawrzeć tu kilku dodatkowych zdań komentarza.

Jak była już wcześniej mowa, zdaje się nie ulegać wątpliwości, że późniejszy ordynariusz wileński $\mathrm{z}$ lat 1730-1762 otrzymał sakrę z rąk Konstantego Kazimierza Brzostowskiego, ewentualnie Aleksandra Horaina. Tego ostatniego - wówczas pasterza diecezji żmudzkiej, wcześniej natomiast kolejno sufragana wileńskiego i ordynariusza smoleńskiego - nie należy mylić (co również już zaznaczono) z jego krewniakiem i imiennikiem, długoletnim sufraganem żmudzkim, który to właśnie konsekrował w roku 1762 Ignacego Jakuba Massalskiego, samemu reprezentując linię rzymską, podczas gdy starszy z Horainów święcenia biskupie przyjął właśnie z rąk K. K. Brzostowskiego, a w konsekwencji był przedstawicielem tej samej linii, co ów ostatni. Należy zatem postawić pytanie, jaką linię reprezentował biskup Brzostowski? $\mathrm{W}$ gronie episkopatu znalazł się on jeszcze $\mathrm{w}$ roku 1685, prekonizowany $30 \mathrm{IV} \mathrm{tr}$.

${ }^{77}$ K. R. Prokop, Sukcesja apostolska biskupów i arcybiskupów wileńskich, dz. cyt., s. 207. 
(1666)

Paluzzo Paluzzi Altieri degli Albertoni

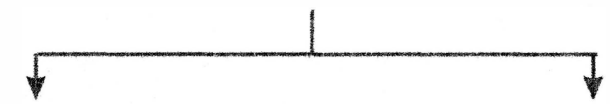

(1721)

Francesco Barberini

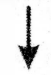

(1730)

Annibale Albani

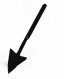

(1732)

Federico Maria Lante

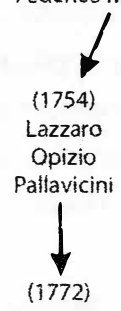

Giuseppe

Garampi

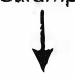

(1774)

Walenty

Wolczacki

Lante
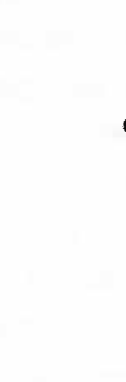

(1670)

Gaspare Di Carpegna

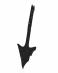

(1695)

Fabrizo Paolucci
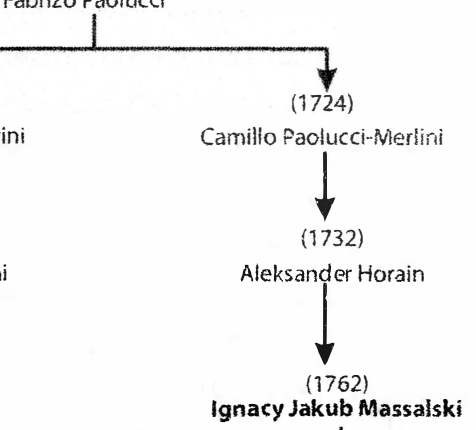

Camillo Paolucci-Mierlini

(1732)

Aleksander Horain
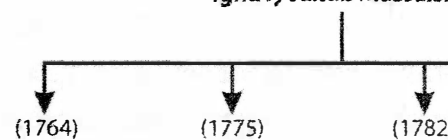

Jan Józef Franciszek

Stefan

Giedroyć

Kazimierz

Alojzy

Gzowski

(1675)

BENEOYKT XIII

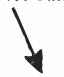

(1724)

BENEDYKT XIV

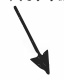

(1743)

KLEMENS XIII

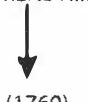

Gian Francesco Albani

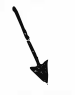

(1773)

Carlo Rezzonico

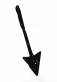

(1775)

Giovanni

Andrea

Archetti

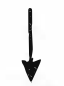

(1777)

Józef

Prószyriski

Schemat nr 1 


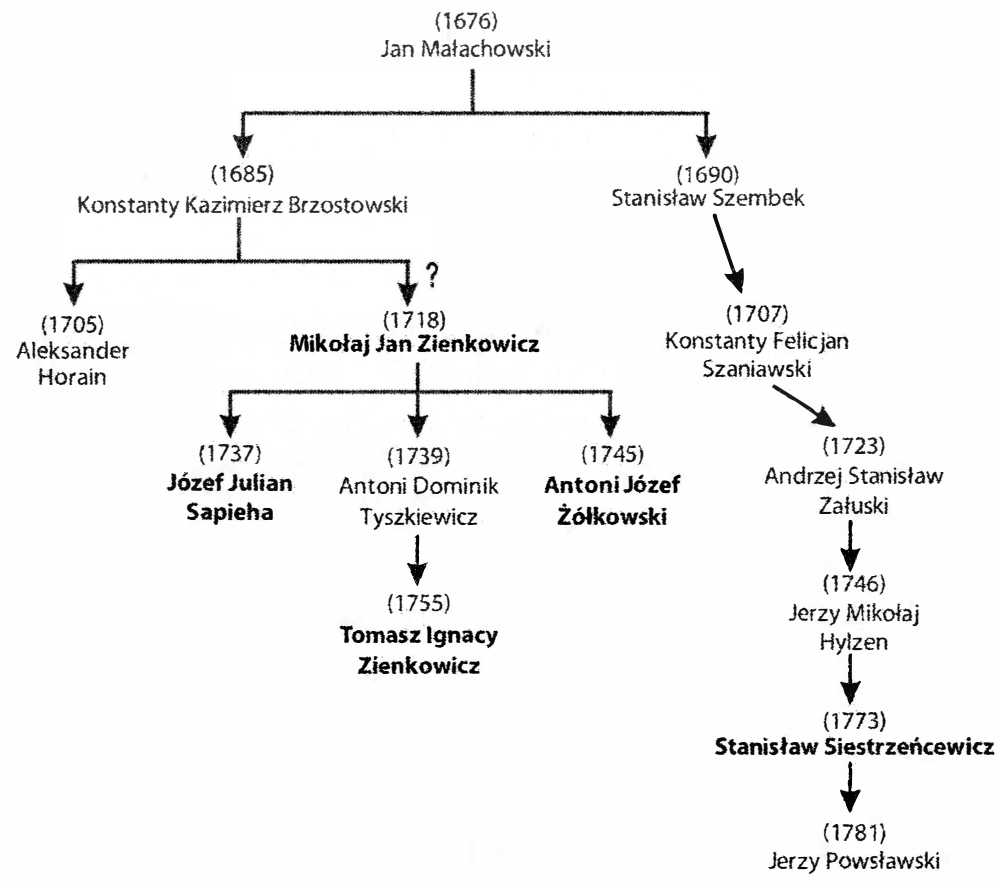

Schemat $\mathrm{nr} 2$

przez papieża Innocentego XI ordynariuszem smoleńskim ${ }^{78}$. Sakra Konstantego Kazimierz Brzostowskiego - jak to wynika jednoznacznie ze stosownego wpisu w księdze „episkopaliów” ordynariusza krakowskiego Jana Małachowskiego - odbyła się 15 VII 1685 r. w Kielcach (niewątpliwie w tamtejszej kolegiacie) ${ }^{79}$. Choć w odnośnej zapisce nie zostało to wyrażone expressis verbis ${ }^{80}$, zdaje się nie ulegać wątpliwości, że konsekratorem był właśnie biskup Małachowski, skoro

${ }^{78}$ Akta procesu informacyjnego: ASV, Archivio Concistoriale, Processus Consistoriales, vol. 83, k. 452r-463v (gdzie na k. 459r-v formuła professio fidei, które to wyznanie wiary desygnowany na biskupstwo smoleńskie sekretarz wielki litewski Konstanty Kazimierz Brzostowski wykonał 12 X 1684 roku na ręce dotychczasowego ordynariusza smoleńskiego Aleksandra Kotowicza, nominata na stolicę biskupią w Wilnie).

79 Archiwum Kurii Metropolitalnej w Krakowie, sygn. AEp 69: [Acta episcopalia Ioannis Małachowski ab anno 1685 ad annum 1688], k. 170v.

${ }^{80}$ Gwoli ścisłości należy sprecyzować, że w rzeczonym tomie „Acta episcopalia” widnieje tylko nagłówek o brzmieniu: Solis XV Julii Kielciis. Consecratio episcopi Smolenscensis, poniżej zaś pozostawiono puste miejsce na dokonanie stosownego wpisu o charakterze urzędowym, odnoszącego się do owej sakry, czego jednak $\mathrm{z}$ niewiadomych względów nigdy nie uczyniono. 
wpis ów widnieje w tomie jego urzędowych akt, a prócz tego Kielce stanowiły ulubioną rezydencję pasterzy Kościoła krakowskiego w tamtym okresie, gdzie niektórzy z nich przebywali nawet o wiele częściej, aniżeli w samym Krakowie. Tymczasem fakt przynależności J. Małachowskiego właśnie do polskiej linii sukcesji święceń biskupich jest od dawna wiadomy badaczom, od tego też hierarchy wyprowadzamy schemat $\mathrm{nr} 2$.

Na zakończenie podjętej tu analizy godzi się wyrazić nadzieję, że dalsze kwerendy źródłowe pozwolą na przedstawienie w przyszłości problematyki sukcesji apostolskiej pasterzy diecezji wileńskiej także $\mathrm{w}$ odniesieniu do wcześniejszych jeszcze okresów. Wymaga to wszakże żmudnych poszukiwań w bardzo rozproszonym i do tego tylko fragmentarycznie zachowanym materiale źródłowym, którego ogarnięcie przekracza jednak możliwości pojedynczego badacza. Oby tedy powyższy artykuł zachęcił również innych historyków Kościoła, także z Litwy, do zainteresowania się ową dotychczas mocno zaniedbywaną w perspektywie badawczej tematyką.

\section{Errata do artkułu:}

Krzysztof R. Prokop, Sukcesja apostolska biskupów i arcybiskupów wileńskich oraz białostockich w XIX i XX stuleciu, „Rocznik Teologii Katolickiej” 4 (2005), s. 165- 210.

\begin{tabular}{|l|l|l|}
\hline Strona (Wiersz od góry) & Jest & Winno by \\
\hline 165 (nagłówek z tytułem) & rcybiskupów & arcybiskupów \\
\hline 169 (wiersz 12) & dignitŕ & dignità \\
\hline 169 (wiersz 12) & qualitŕ́ & qualità \\
\hline 179 (wiersz 13) & $\underline{10 X I I}$ & 10 XII \\
\hline 202 (tabela: kol. 4, wiersz 6) & $\begin{array}{l}\text { Poniewiè̇, katedra } \\
\text { Chrystusa Króla }\end{array}$ & $\begin{array}{l}\text { Poniewież, katedra } \\
\text { Przemienienia Pańskiego }\end{array}$ \\
\hline 203 (tabela: kol. 6, wiersz 5) & gr.-kat.Biskup & gr.-kat. biskup \\
\hline 206 (przypis 89, wiersz 8) & Espańol & Español \\
\hline 207 (przypis 89, wiersz 2-3) & Espańol & Español \\
\hline 207 (przypis 89, wiersz 2) & Espańoles & Españoles \\
\hline 208 (schemat: kol. 1, poz. 11) & Backis & Bačkis \\
\hline 208 (schemat: kol. 2, poz. 12) & Sladkevicius & Sladkevičius \\
\hline
\end{tabular}

